\title{
The Effects of Maternal Parenting Stress Trajectory on Affective Parenting and Socioemotional Development of Preschooler: Differences Between Employed and Unemployed Mothers
}

\author{
Saerom Park ${ }^{1}$, Hye Jun Park ${ }^{1,2}$ \\ Department of Child Development and Family Studies, Seoul National University, Seoul, Korea ${ }^{1}$ \\ Research Institute of Human Ecology, Seoul National University, Seoul, Korea ${ }^{2}$ \\ 영아 자녀를 둔 어머니의 양육스트레스 변화가 온정적 양육행동 및 \\ 유아의 사회정서발달에 미치는 영향: 어머니 취업여부에 따른 차이 \\ 박새롬 ${ }^{1}$, 박혜준 $^{1,2}$ \\ 서울대학교 아동가족학과 ${ }^{1}$, 서울대학교 생활과학연구소 ${ }^{2}$
}

Objective: This study aimed to investigate the trajectory of maternal parenting stress during infancy according to the employment status of mothers when each year's depression was controlled and examine the longitudinal effects of parenting stress on affective parenting and socioemotional developmental outcomes for preschoolers.

Methods: Using latent growth modeling, the first 4 waves of panel data collected from 2,078 mothers and their babies were analyzed. This nationwide data was provided from the 2008 Panel Study on Korean Children, conducted by the Korea Institute of Child Care and Education.

Results: First, maternal parenting stress showed a linear increasing pattern, and there were individual differences in intercept and slope. Second, when each year's maternal depression was controlled, the intercept of parenting stress was lower, but the rate of increase was higher. In multiple group analyses, this increasing pattern of parenting stress was significant only in unemployed mothers. Lastly, the increase of unemployed mothers' parenting stress had direct effects on child emotionality and peer interaction and had an indirect effect on child peer interaction (mediated by affective parenting).

Conclusion: The current study verified that the longitudinal effects of increasing parenting stress of unemployed mothers on affective parenting and child socioemotional development when maternal depression level was controlled. These results imply that we need to pay more attention to emotional health and resources of unemployed mothers and provide them with social support as well as employed mothers.

Keywords: trajectory of parenting stress, depression, emotionality, peer interaction, affective parenting

Corresponding Author: Hye Jun Park, Department of Child Development and Family Studies, Seoul National University, 1 Gwanak-ro, Gwanak-gu, Seoul, Korea

E-mail: hyejun@snu.ac.kr (c) The Korean Association of Child Studies

This is an Open Access article distributed under the terms of the Creative Commons Attribution Non-Commercial License (http:// creativecommons.org/licenses/by-nc/4.0) which permits unrestricted noncommercial use, distribution, and reproduction in any medium, provided the original work is properly cited. 


\section{서론}

영아는 생애 초기 주양육자와의 상호작용을 통하여 애착을 형성하고, 이 시기 관계의 질은 이후 사회정서발달 및 대인관 계의 기초(Fonagy, Gergely, Jurist, \& Target, 2002; Grossmann, Grossmann, \& Waters, 2005)가 된다는 점에서 영아의 일차적 환경으로서의 주양육자의 역할이 중요하게 여겨지고 있다. 특 히 부모의 민감하고 반응적인 상호작용이 자녀의 건강한 발 달을 촉진시키는 것으로 알려져 왔다(Music, 2011). 선행연구 들을 살펴보면, 어머니가 더 민감하게 반응할수록 유아는 자 신의 부정적 정서를 더 잘 다룰 수 있으며, 덜 반응적인 어머 니의 유아는 부정적 정서를 더 많이 경험하고 부정적 정서로 부터 회복되는 시간도 더 오래 걸리는 것으로 나타났다(Field, Diego, \& Hernandez-Reif, 2006). 최근 연구들은 특히 정서적 으로 취약한 영아의 경우 어머니의 부정적인 양육행동은 위 험 요인으로, 긍정적인 양육행동은 보호 요인으로 작용한다 는 것을 밝혔다. 영아기에 예민하고 쉽게 우는 등 부정적 정서 성이 높았던 아동은 강압적이고 거부적인 양육을 경험하였을 때 이후의 정서 및 행동문제가 그렇지 않은 아동에 비해 더 높 게 나타났으며(Belsky, Hsieh, \& Crnic, 1998; Morrell \& Murray, 2003), 동시에 까다로운 기질 및 부정적 정서 수준이 높은 아 동이 지지적이고 민감한 양육을 경험하였을 때 중재 효과 또 한 가장 높았던 것으로 나타났다(Pluess \& Belsky, 2010). 이러 한 연구결과들은 사회정서발달의 기초가 형성되는 시기인 영 아기에 일차적 상호작용 환경으로서의 어머니의 역할을 강조 하며 관련 변인들에 대한 연구가 필요함을 시사한다.

많은 연구들은 모-자녀 상호작용에 영향을 미치는 주된 요인으로 어머니의 정서적 건강에 관심을 가져왔다(DeaterDeckard, 1998; Field, 2010). 영아기 자녀를 가진 어머니들에 게 나타날 수 있는 정서적 위험 요인으로는 양육스트레스 (parenting stress)를 들 수 있다. 양육스트레스는 부모 역할을 수 행함으로써 느끼는 스트레스의 한 유형으로, 자녀의 양육으 로 인하여 곤란함이나 부담감을 인지하는 정도를 의미한다 (Coplan, Bowker, \& Cooper, 2003). 출산과 함께 신체적·심리적 으로 큰 변화를 경험하고, 수유, 배변, 수면 등과 관련된 실제 적인 돌봄 요구가 가장 큰 시기인 영아기에는 주양육자인 어 머니의 양육부담이 가중될 수 있다. 특히 첫 자녀인 경우 어머 니는 부모라는 새로운 역할을 수용하고 적응해야 하는 이중의 도전에 직면하게 된다.

어머니의 높은 양육스트레스는 자녀의 다양한 발달 영역 에 직접 영향을 미치기도 하고, 일상적 양육행동을 통해 영아
와의 상호작용에 반영됨으로써 간접적으로 영향을 미칠 수 도 있다(Crnic, Gaze, \& Hoffman, 2005). 영아기 자녀를 둔 어 머니의 양육스트레스는 영아의 불안정 애착 및 문제행동과 같 은 정서행동문제에 직접적인 영향을 미치는 것으로 나타났다 (Cummings, Davies, \& Campbell, 2000). 유아의 경우에도 어머 니의 양육스트레스 수준이 높을수록 또래관계 및 정서와 관 련된 문제들을 더 많이 보였다(Anthony et al., 2005). 뿐만 아니 라 양육스트레스는 부적절한 상호작용 및 양육행동을 매개로 하여 자녀의 적응 및 발달에 부정적인 영향을 미치는 것으로 나타났다(Deater-Deckard, 1998). 양육스트레스가 높은 어머 니는 양육행동에 있어서 영아의 신체적-정서적 요구에 대하 여 민감하게 반응하지 못하며(Abidin, 1992; Shin, 2011), 이는 영아에게 더욱 요구적이고 까다로운 반응을 이끌어내게 된다 (Chung, Kang, \& Choi, 2014).

양육행동 및 자녀의 발달에 영향을 미치는 요인으로서 어 머니의 양육스트레스를 다룬 지금까지의 연구들은 대부분 발 달의 특정 시점에서 양육스트레스를 살펴보았다는 한계가 있 다. 모-자녀 관계는 일생 동안 지속되는 관계이며 관계의 특 성은 장기적이고 누적적인 영향력을 미친다(de Mol \& Buysse, 2008)는 점을 고려할 때, 양육스트레스 또한 장기적인 관점 에서 살펴볼 필요가 있다. 영아 자녀를 둔 어머니 양육스트 레스의 변화 양상에 대한 국외 종단연구들을 보면, 출산 후 2 세까지는 양육스트레스가 증가하다가 2세를 기점으로 유아 기를 거치면서 감소하기 시작한다는 결과들이 있다(Mulsow, Caldera, Pursley, Reifman, \& Huston, 2002; Williford, Calkins, \& Keane, 2007). 또한 3-5세 유아 자녀를 둔 어머니를 대상으로 양육스트레스를 살펴본 연구에서는 양육스트레스 변화 양상 은 안정적이었으나 누적된 스트레스가 모-자녀 간 상호작용 및 양육행동에 영향을 미치고, 유아의 발달에 문제를 일으킬 가능성이 높다는 것을 입증하였다(Crnic et al., 2005). 패널데 이터를 활용한 국내 연구들에서도 양육스트레스의 변화 양상 을 검증하였다. 출산 후부터 자녀가 3세가 되는 시점까지 양육 스트레스는 선형적으로 증가하였고, 4세가 되는 해인 5차년 도 자료를 분석에 포함하였을 때에는 그 증가폭이 점차 감소 하면서 매년 꾸준히 증가하는 양상을 보이는 것으로 나타났다 (S. Park, No, Park, \& Yi, 2015). 이와 같은 종단분석을 통해 영 유아기 자녀를 키우는 우리나라 어머니의 양육스트레스 변화 양상이 국외 연구와는 달리 출산 후부터 지속적으로 증가하는 경향을 보인다는 것을 알 수 있으며, 이는 관련된 예측변인 및 결과변인들에 대한 후속 연구의 필요성을 강조한다. 지금까지 이루어진 국내 연구들은 어머니의 사회인구학적 특성, 어머니 
의 양육방식 및 정서적 특성, 아버지의 양육참여 및 부부갈등, 영아의 기질, 보육기관 이용 및 육아지원서비스 등 다양한 변 인들이 양육스트레스 변화 궤적에 나타나는 개인차에 영향을 미친다는 것을 밝혀냈다(Choi, Yeon, Kwon, \& Hong, 2013; H.-

J. Lee, 2013; J. Lee \& Lee, 2013; S. Park et al., 2015; Shin, 2011). 그러나 양육스트레스 변화의 개인차에 영향을 미치는 예측변 인뿐만 아니라, 이러한 양육스트레스의 종단적 변화가 선행 연구들에서 밝혀진 어머니의 양육행동 및 유아의 발달과 같은 결과변인들에 어떠한 영향력을 미치는가를 살펴본 연구는 아 직 부족하다. 따라서 본 연구에서는 영아기 자녀를 키우는 동 안 어머니의 양육스트레스 변화가 이후 온정적 양육행동 및 유아의 사회정서발달에 미치는 영향력을 종단적으로 검증하 고, 선행연구 결과를 근거로 온정적 양육행동의 매개효과 또 한 확인하고자 한다.

국내외 연구들을 종합해보면, 자녀가 출생 후 만 2-3세에 이르는 영아기 동안 어머니의 양육스트레스는 선형적으로 증 가하는 추세이지만 변화 양상에는 개인차가 있고, 다양한 변 인들이 개인차에 영향을 미친다는 것을 알 수 있다. 선행연구 들에서 살펴본 예측변인들은 대체로 한 시점에서 측정된 자 료이므로, 각 시점별로 변화하는 변인을 통제할 경우 양육스 트레스의 변화 추이를 더욱 정확히 살펴볼 수 있을 것이다. 이 에 본 연구에서는 어머니의 양육스트레스와 밀접한 관련이 있 는 또 다른 정서적 변인인 우울에 주목하였다. 산후 우울과 양 육스트레스는 부모로의 전이 과정에 있어서 가장 흔하게 경험 할 수 있는 심리적 위기이며(Epifanio, Genna, de Luca, Roccella, \& la Grutta, 2015), 어머니의 우울은 양육스트레스에 직접 영 향을 미치는 주된 요인 중 하나이다(Han, Kim, \& Cho, 2014), 감정의 기복이 심하고 무기력을 동반하는 우울한 어머니에 게 돌봄 요구가 특히 높은 영아를 양육하는 것은 더욱 힘들 고 스트레스를 유발하는 것으로 지각될 수 있다. 선행연구들 에 따르면 우울한 어머니는 영아가 보내는 신호를 잘 읽지 못 할 뿐 아니라 즉각적으로 반응하지 못하는 경향을 보이며, 강 압적이거나 철회적인 상호작용 특성을 나타낸다(Field, 2005). 산후우울을 경험하거나 전반적 민감성이 낮은 어머니의 영 아들은 공동주의(joint attention)의 수준이 더 낮았고(Gaffan, Martins, Healy, \& Murray, 2010), 운동 및 정서 발달이 지연되 었으며(Murray \& Cooper, 1997), 장기적으로는 유아기의 불안 정 애착과 분리 불안, 학령기의 또래관계 및 내면화·외현화 문 제와도 관련이 있는 것으로 나타났다(Kam et al., 2011; Martins $\&$ Gaffan, 2000). 이렇듯 어머니의 우울은 양육스트레스의 지 각에 영향을 미칠 수 있으며, 자녀의 사회정서발달에 직접적
이고 장기적인 영향력뿐만 아니라 양육스트레스를 매개로 하 여 간접적으로 영향을 미칠 수 있다는 연구결과들(H.-O. Kim, 2015; H.-J. Lee, 2011)로 미루어볼 때, 각 시점에서 측정된 어 머니의 우울을 예측변인으로 통제한다면 영아기 어머니의 양 육스트레스 변화가 이후의 결과에 미치는 영향력을 더욱 명확 히 밝힐 수 있을 것이다.

한편, 양육스트레스의 변화 양상 및 양육스트레스의 변화 가 이후 어머니의 양육행동과 유아의 사회정서발달에 미치 는 영향력의 정도는 어머니의 취업여부에 따라 달라질 수 있 다. 자녀와 함께 보내는 절대적 시간과 자녀양육에 활용 가능 한 자원이 서로 다른 전업모와 취업모 간에는 양육스트레스에 대한 지각 및 평가뿐만 아니라 양육행동의 실제에서도 차이 가 나타날 것으로 예측된다. 횡단연구 결과들을 살펴보면 출 산 후 3 년간 각 시점별로 전업유지 어머니와 취업유지 어머니 의 양육스트레스를 비교한 연구에서는 전업유지 어머니의 양 육스트레스가 매 시점에서 더 높게 나타났으며(Song, Lee, \& Chun, 2014), 이 외에도 최근 연구들은 전업모의 양육스트레 스가 취업모보다 높은 것으로 지속적으로 보고하고 있다(Jo,

Chung, \& Lee, 2015; Kwon, 2011; Y. Lee \& Chin, 2013; Son et al., 2010). 이와 달리 취업여부에 따라 어머니의 양육스트레 스에는 차이가 없는 것으로 나타난 연구도 다수 존재하였다 (Han et al., 2014; K.-W. Kim, Doh, Kim, \& Rhee, 2010). 종단연 구 결과에서는 전업모 양육스트레스의 초기치가 취업모에 비 해 더 높고, 전업모의 양육스트레스만 시간에 따라 유의하게 증가하는 양상이 나타났다(S. Park et al., 2015). 이 연구에서 취 업모의 양육스트레스는 시간에 따른 변화가 없는 것으로 나타 났는데, 어머니 취업여부는 양육스트레스 변화 양상에 대한 조절효과가 있으며 양육스트레스 변화와 관련 변인들 간의 관 계를 살펴볼 때 취업여부에 따라 구분하여 분석할 필요가 있 음을 알 수 있다. 선행연구 결과들을 종합하면 전업모와 취업 모의 양육스트레스를 횡단적으로 비교한 연구결과들은 일관 적이지 않으며(K.-W. Kim et al., 2010; Sohn, 2012), 특히 양육 스트레스의 변화 및 관련 변인들 간의 종단분석은 아직 부족 한 실정이므로 이에 대한 후속 연구가 이루어질 필요가 있다.

따라서 본 연구에서는 한국아동패널데이터 1-4차 연도 (2008-2011년) 자료를 활용하여 출산 직후부터 영아기 자녀 를 키우는 동안 어머니의 양육스트레스가 어떠한 양상으로 변 화하는지 확인하고, 각 시점에서 어머니의 우울을 예측변인으 로 통제하였을 때 양육스트레스의 변화 추이가 어떻게 달라지 는지 살펴본 후 어머니 취업여부에 따라 비교 분석하고자 한 다. 또한 우울을 통제한 경우 양육스트레스의 변화 궤적이 이 
후의 주요 결과변인, 즉 어머니의 온정적 양육행동과 유아의 사회정서발달에 어떠한 영향을 미치는지 어머니 취업여부에 따라 비교함으로써 영아기 자녀를 키우는 동안 어머니의 정서 적 건강과 이후의 양육행동 및 유아의 사회정서발달 간의 구 조관계를 종단적으로 분석하고 이에 대한 논의를 이끌어내고 자 한다.

위와 같은 연구목적에 따라 다음의 연구문제를 설정하였 다.

\section{연구문제 1}

영아기(0-3세) 자녀를 키우는 동안 어머니의 양육스트레스 변화 궤적은 어떠한가?

\section{연구문제 2}

영아기(0-3세)의 각 시점에서 우울을 통제하였을 때 어머니 의 양육스트레스 변화 궤적은 어떠하며, 이는 어머니의 취업 여부에 따라 어떻게 다른가?

\section{연구문제 3}

영아기(0-3세)의 각 시점에서 우울을 통제하였을 때 어머니 의 양육스트레스 변화 궤적, 3 세 때 어머니의 온정적 양육행 동, 3 세 유아의 사회정서발달(정서성, 또래상호작용) 간의 구 조관계는 어떠하며, 이는 어머니의 취업여부에 따라 어떻게 다른가?

\section{연구방법}

\section{연구대상}

본 연구는 Korea Institute of Child Care and Education (KICCE; 2008-2011)에서 실시한 한국아동패널연구(Panel Study on Korean Children)의 1-4차 연도 자료를 분석하였다. 한국아동 패널의 표본은 2008년 4월부터 7월 사이에 출생한 신생아가 있는 총 2,078개 가구를 대상으로 하여 패널 아동이 만 0세부 터 7세가 될 때까지 매년 1회, 이후 만 9세와 12세에 각 1회씩 총 10 차에 걸쳐 구축되는 데이터이다. 영아기 자녀를 키우는 어머니의 양육스트레스 변화 궤적을 살펴보기 위하여 4 개 시 점에서 측정된 자료, 즉 자녀가 만 3 세가 되는 시점까지의 자 료를 포함하였다. 영아기의 연령 범위는 학문영역에 따라 다 양하게 정의되는데, 일반적으로 만 2 세까지를 영아기에 포함
한다. 본 연구에서는 시간의 흐름에 따른 변화 추이를 더욱 명 확하게 살펴보고, 영아 자녀를 둔 어머니의 양육스트레스 변 화가 유아기의 발달에 미치는 영향을 종단적으로 검증한다는 연구 목적에 부합하는 분석모형 설정을 위하여 자녀가 만 3세 가 되는 4차 연도 자료까지 포함하여 분석하였다. 한국아동패 널데이터 1 차 연도의 표본 추출에는 층화 다단계 표본추출법 이 적용되었으며 1 차 연도에 총 2,078 가구, 2 차 1,904 가구, 3 차 1,802 가구, 4 차 1,754 가구가 조사에 참여하여 4 차 연도까지 표 본유지율은 $84.4 \%$ 이었다.

\section{연구도구}

양육스트레스

한국아동패널조사의 양육스트레스 척도는 Kim과 Kang (1997) 이 Abidin (1990)의 Parenting Stress Index-Short Form (PSI-SF), Crnic과 Greenberg (1998)의 Parenting Daily Hassles (PDH), 그 리고 Mann과 Thornberg (1987)의 Maternal Guilt Scale (MGS) 을 기초로 한국형으로 개발한 “양육스트레스 척도" 중 "부모 역할에 대한 부담감 및 디스트레스" 문항을 발췌하여 사용하 였다. 이는 부모역할 수행에 따른 부담감과 부모가 인지하는 어려움을 반영하는 총 12 문항으로 구성된 척도이다. 6 세 이 하 영유아 자녀를 둔 부모를 대상으로 하는 척도로, 1,2 차 연 도에는 문항 진술의 부정확성 및 연령 부적합 등으로 인해 2 문항이 제외된 총 10 문항으로 조사되었고, 3,4 차 연도에는 연 령 부적합으로 제외되었던 1문항을 포함시켜 총 11 문항으로 조사가 이루어졌다. "좋은 부모가 될 수 있을지 확신이 서지 않는다.", "아이가 태어난 후 예전만큼 나의 생활이 즐겁지 않 다.” 등의 문항으로 구성되어 있다. 5점 리커트 척도(1: 전혀 그 렇지 않다 5: 매우 그렇다)로 측정되어 점수가 높을수록 양 육스트레스가 높다는 것을 의미한다. 이 척도의 문항신뢰도 Cronbach's $\alpha$ 는 1 차 $.84,2$ 차 .85, 3차.87, 4차.87이었다.

\section{우울}

한국아동패널조사에서는 신생아 패널을 대상으로 한 2008년 도 조사에서 어머니의 우울 수준을 출산 직후, 출산 후 1 개월 시점, 그리고 출산 후 4 개월 시점에서 3 차에 걸쳐 측정하였다. 1 차 연도에 동일한 척도를 사용하여 3 회에 걸쳐 실시한 조사 에서 각각 지난 30 일 간의 우울감을 측정하였으며, 이후 2 차 연도부터 4차 연도까지는 매년 1회 측정하였다. 2013년 개정 
된 미국정신의학회 진단기준인 DSM-V에 따르면 산후우울증 은 출산 후 4 주 이내에 발생하여 1 년 이상 지속되는 경우를 의 미하며, 출산 이후 어머니들이 흔히 경험하는 미약한 우울 증 세는 2 주 안에 개선되는 것으로 알려져 있다(Wisner, Parry, \& Piontek, 2002). 따라서 본 연구에서는 일시적인 산후우울과 구 별되는 매 시점에서의 전반적 우울 수준을 분석에 활용하기 위하여 출산 후 4 개월 시점에서 측정된 우울 점수를 1 차 연도 측정치로 하여 4 차 연도까지의 점수를 사용하였다. 조사에 사 용된 척도는 Kessler 우울 척도(K6; Kessler et al., 2002)로, "불안 하셨습니까?”, “무기력하셨습니까?” 등 총 6 문항으로 구성되 어 있다. 5점 리커트 척도(1: 전혀 안 느낌 5: 항상 느낌)로 응답하도록 하였으며 점수가 높을수록 더 우울하다는 것을 의 미한다. 이 척도의 문항신뢰도 Cronbach's $\alpha$ 는 $1-4$ 차 연도 모 두 .91로 높게 나타났다.

\section{온정적 양육행동}

4차 연도 어머니의 온정적 양육행동을 알아보기 위하여 한국아동패널조사에서 양육스타일 질문지(Parental Style Questionnaire [PSQ]; Bornstein et al., 1996)를 통해 측정한 자료 를 사용하였다. PSQ는 사회적 양육유형(9문항), 가르치는 양 육유형(5문항), 한계설정 양육유형(3문항)의 3 가지 하위영역 으로 구성된 총 17 문항 척도이다. 한국아동패널조사에서는 이 중 “사회적 양육유형” 척도 9문항을 발췌하였으며 이는 어 머니의 온정성과 반응성을 포함하는 관계적 특성을 측정하는 하위영역이다(KICCE, 2009). "나는 우리 아이가 힘들어하거 나 불편해하면 즉시 적절하게 반응한다.", "나는 우리 아이에 게 긍정적이고 애정적이며 따뜻한 관심을 보인다.” 등의 문항 으로 구성되어 있으며, 5점 리커트 척도(1: 전혀 그렇지 않다 5: 매우 그렇다)로 측정되어 점수가 높을수록 반응적이고 온정적인 양육행동임을 의미한다. 척도의 하위변인명은 사회 적 양육유형이나, 본 연구에서는 척도 의미 파악을 더욱 용이 하게 하고자 문항 내용 및 요인 분석 결과(KICCE, 2009)를 고 려하여 '온정적 양육행동'으로 개념화하였다. 4차 연도 온정적 양육행동 척도의 문항신뢰도 Cronbach's $\alpha$ 는 .87이었다.

\section{유아의 사회정서발달}

본 연구에서는 4차 연도 만 3세 유아의 사회정서발달에 대한 지표로 유아의 정서성 기질과 또래 상호작용을 살펴보았다. 정서성 기질은 유아의 정서적인 특성을, 또래 상호작용은 사
회적 관계에서의 행동 특성을 반영하는 것으로 보았다. 유아 의 정서성 기질은 Buss와 Plomin (1984)의 부모용 EAS 기질척 도(Emotionality, Activity, and Sociability) 20 문항 중 정서성 하위 영역 5 문항 척도를 통해 측정되었다(KICCE, 2008). 정서성 척 도는 "우리 아이는 다소 감정적인 편이다.”, “우리 아이는 종 종 보채면서 우는 편이다.” 등의 문항으로 구성되었다. 5점 리 커트 척도(1: 전혀 그렇지 않다 5: 매우 그렇다)로 측정되었 으며 점수가 높을수록 부정적인 정서표현의 빈도와 강도가 더 높은 것으로 해석할 수 있다. 정서성은 선천적으로 타고나는 기질적인 특성으로 볼 수 있으나(Rothbart \& Bates, 1998), 실 제로 한국아동패널데이터의 1-4차 연도 자료에서 어머니가 평가한 유아의 정서성 평균은 각각 $2.72,2.71,2.84,2.87$ 로 매 년 유의하게 증가하는 것으로 나타났다. 정서성 잠재성장모 형(무조건모형)의 모형적합도는 $\chi^{2}=65.382(d f=5, p<.001)$, $\mathrm{TLI}=.920, \mathrm{CFI}=.960$, RMSEA $=.075$ (90\% CI $[.059, .092])$ 로 타당하였으며, 정서성 초기치는 2.698 , 변화율은 .058이었 다 $(p<.001)$. 따라서 본 연구에서는 유아의 정서성을 시간에 따라 변화할 수 있는 특성으로 보았으며, 다양한 변인 중 양육 스트레스 변화 및 양육행동이 어머니가 유아의 정서성을 평가 하는 데 영향을 미칠 수 있을 것으로 가정하여 연구모형을 설 정하였다. 4 차 연도 정서성 척도의 문항신뢰도 Cronbach's $\alpha$ 는 .73이었다.

유아의 또래 상호작용은 4차 연도에 처음으로 측정되었 으며, 한국아동패널조사에서는 Fantuzzo 등(1995)의 연구 및 Choi와 Shin (2008)의 또래 상호작용 척도 문항을 토대로 재구 성한 척도를 사용하였다. 놀이상호작용(9문항), 놀이방해(13 문항), 놀이단절(8문항)의 3 가지 하위영역 총 30 문항으로 구 성되었으며 어머니와 교사가 각각 응답하도록 하였다. 본 연 구에서는 4 차 연도 교사 평정 자료의 결측률(총 1,754 명 중 $54.4 \%$ )이 어머니 평정 자료의 결측률(총 1,754 명 중 $4.5 \%$ )보 다 매우 높았던 점을 고려하여 어머니가 응답한 자료를 사용 하였다. 어머니 평정 자료는 5점 리커트 척도(1: 전혀 그렇지 않다 5: 항상 그렇다)로 측정되었다. 각 하위영역별 문항내 용을 살펴보면 놀이상호작용은 친사회적인 특성과 놀이를 순 조롭게 이어가는 특성을 측정하며 “친구를 돕는다.", "친구 사 이의 갈등이 해결되도록 돕는다.” 등의 문항으로 구성되었다. 놀이방해는 공격적이고 부정적인 정서표현을 측정하며 “몸 싸움이나 말싸움을 시작한다.”, “차례를 지키지 않는다.” 등의 문항으로 구성되었다. 놀이단절은 위축되거나 타인에게 무시 또는 거부당하는 특징을 측정하며 "다른 친구에게 거부당한 다.", "위축되어 있다." 등의 문항으로 구성되었다. 각 하위영 
역의 내용을 살펴보면 놀이상호작용은 긍정적인 또래 상호작 용 특성인 반면 놀이방해와 놀이단절은 부정적인 또래 상호작 용 특성이므로, 기술통계를 제외하고 연구모형의 분석에서는 놀이방해와 놀이단절 문항을 역코딩하여 점수가 높을수록 긍 정적인 또래 상호작용을 의미하도록 하였다. 이 척도의 문항 신뢰도 Cronbach's $\alpha$ 는 놀이상호작용 .80, 놀이방해 .77, 놀이 단절 .81 , 전체 척도 .87 이었다.

\section{연구모형 및 자료 분석}

선행연구를 바탕으로 본 연구에서 검증하고자 하는 연구모형 을 그림으로 나타내면 Figure 1과 같다. 각 시점에서 어머니의 우울을 통제하였을 때 영아기 자녀를 키우는 동안 양육스트레 스가 변화하는 양상이 이후 유아기에 자녀에 대한 온정적 양 육행동에 영향을 미치며, 양육행동을 매개로 하여 유아의 사 회정서발달을 나타내는 정서성과 또래 상호작용에도 영향을 미칠 것으로 가정한 모형을 검증하고자 한다.

자료는 SPSS 20.0 (IBM Co., Armonk, NY) 및 AMOS 20.0 (IBM Co., Armonk, NY) 통계프로그램을 사용하여 분석되었
다. 자녀가 만 0-3세에 해당하는 영아기 동안 어머니 양육스 트레스 변화 양상은 어떠한지, 그리고 이 변화 궤적에 개인 차가 존재하는지 살펴보기 위해 잠재성장모형(latent growth modeling)을 활용하였는데, 각 시점에서 어머니의 우울 수준 을 통제하기 위하여 시간 가변성 공변량 모형(time-varying covariate model)을 설정하여 분석하였다. 이러한 양육스트레 스 변화 궤적과 어머니의 온정적 양육행동, 그리고 유아의 또 래 상호작용 특성 간의 인과관계를 확인하기 위해서는 구조방 정식 모형을 설정하였다. 그리고 이러한 변인들 간 영향력이 어머니의 취업여부에 따라 어떻게 다른지 구체적으로 살펴보 기 위하여 다집단분석을 실시하였다.

결측치는 완전정보최대우도법(full information maximum likelihood)을 사용하여 처리하였다. 이 방법은 종단 조사에 서 발생하게 되는 결측치를 처리하는 데 있어서 결측치가 있 는 사례를 삭제하는 전통적 방식에 비해 더욱 정확한 추정을 할 수 있는 것으로 알려져 있다(Arbuckle, 1996). 모형의 적합 도를 판단하기 위해서는 $\chi^{2}$ 값과 함께 절대적합지수 RMSEA (Root Mean Square Error of Approximation)와 증분적합지수 TLI (Tucker-Lewis Index), CFI (Comparative Fit Index)를 사용

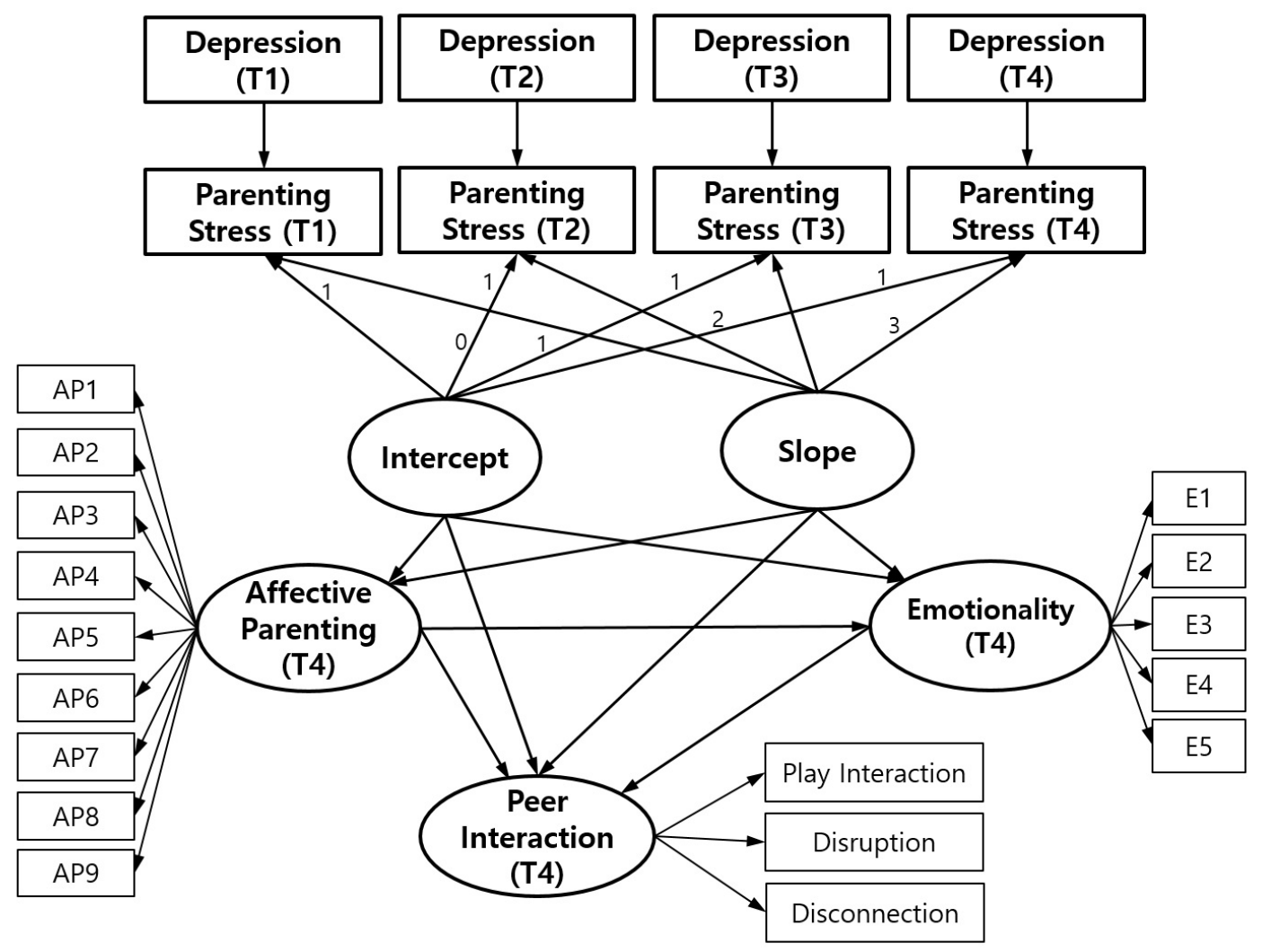

Figure 1. Hypothesis model. 
하였다. $\chi^{2}$ 검증의 경우 유의확률이 .05 이상일 때 검증모형이 데이터를 잘 설명하는 것으로 판단할 수 있다. 그러나 $\chi^{2}$ 검증 은 검증모형이 변수 간의 관계를 완벽히 설명한다는 영가설이 기각되기 쉽고, 그 값이 표본의 크기에 민감하여 표본의 크기 가 클수록 유의확률이 낮아지는 경향이 있다는 점을 고려하여 (Kline, 2005), 적합도지수 RMSEA, TLI, CFI를 함께 고려하여 모형적합도를 판단하였다. 이 적합도지수들은 표본 크기에 민 감하게 영향을 받지 않으며 RMSEA와 TLI의 경우 모형의 간 명성을 고려한다는 장점이 있다(Hong, 2000). RMSEA는 .05 이하일 때, TLI와 CFI는 .90 이상일 때 모형의 적합성이 좋음 을 의미하는 것으로 해석할 수 있다.

\section{연구결과}

\section{기술통계}

본 연구의 주요 변인인 어머니의 양육스트레스, 우울, 온정적 양육행동, 유아의 정서성 및 또래상호작용에 대한 기술통계량 은 Table 1 과 같다.
어머니 양육스트레스 평균은 1 차 연도 $2.74,2$ 차 연도 2.73 , 3 차 및 4차 연도에 2.79로 2차 연도에 소폭 감소하였다가 이후 증가하는 경향을 보였다. 어머니 우울은 양육스트레스 평균보 다는 전반적으로 낮았지만 2차 연도에 소폭 감소 후 증가하는 변화 양상은 유사하게 나타났다. 4 차 연도에 측정된 어머니 온 정적 양육행동은 5점 척도에서 3.80 으로 비교적 높게 나타남 을 알 수 있었다. 4 차 연도에 어머니가 평정한 유아 정서성 점 수는 2.87 로 중간값보다 조금 높은 점수를 나타내었다. 또한 어머니들은 유아의 긍정적 놀이상호작용을 가장 높게(3.45) 평가하였고, 놀이단절(2.40)및 놀이방해(1.95)와 같은 부정적 상호작용은 비교적 낮은 것으로 평가하였다. 본 연구에서 사 용한 완전정보최대우도법을 통해 결과를 도출할 경우 데이터 의 정규성 가정을 충족시키는지의 여부가 중요한데, 각 변인 의 왜도 및 첨도 값을 확인한 결과 각각 $\pm 2, \pm 7$ 미만으로 모두 정상 분포를 가정할 수 있었다(Curran, West, \& Finch, 1996).

또한 본 연구에서는 어머니 취업여부에 따른 비교 분석을 실시할 예정이므로, 각 변인에 대하여 전업모와 취업모 집단 의 기술통계 및 평균비교 결과를 Table 2에 제시하였다. 어머니 의 취업여부는 한국아동패널조사에서 1 차 연도에 조사된 "취 업 및 학업상태” 항목의 응답 결과를 기준으로, 취업 중 또는

Table 1

Descriptive Statistics

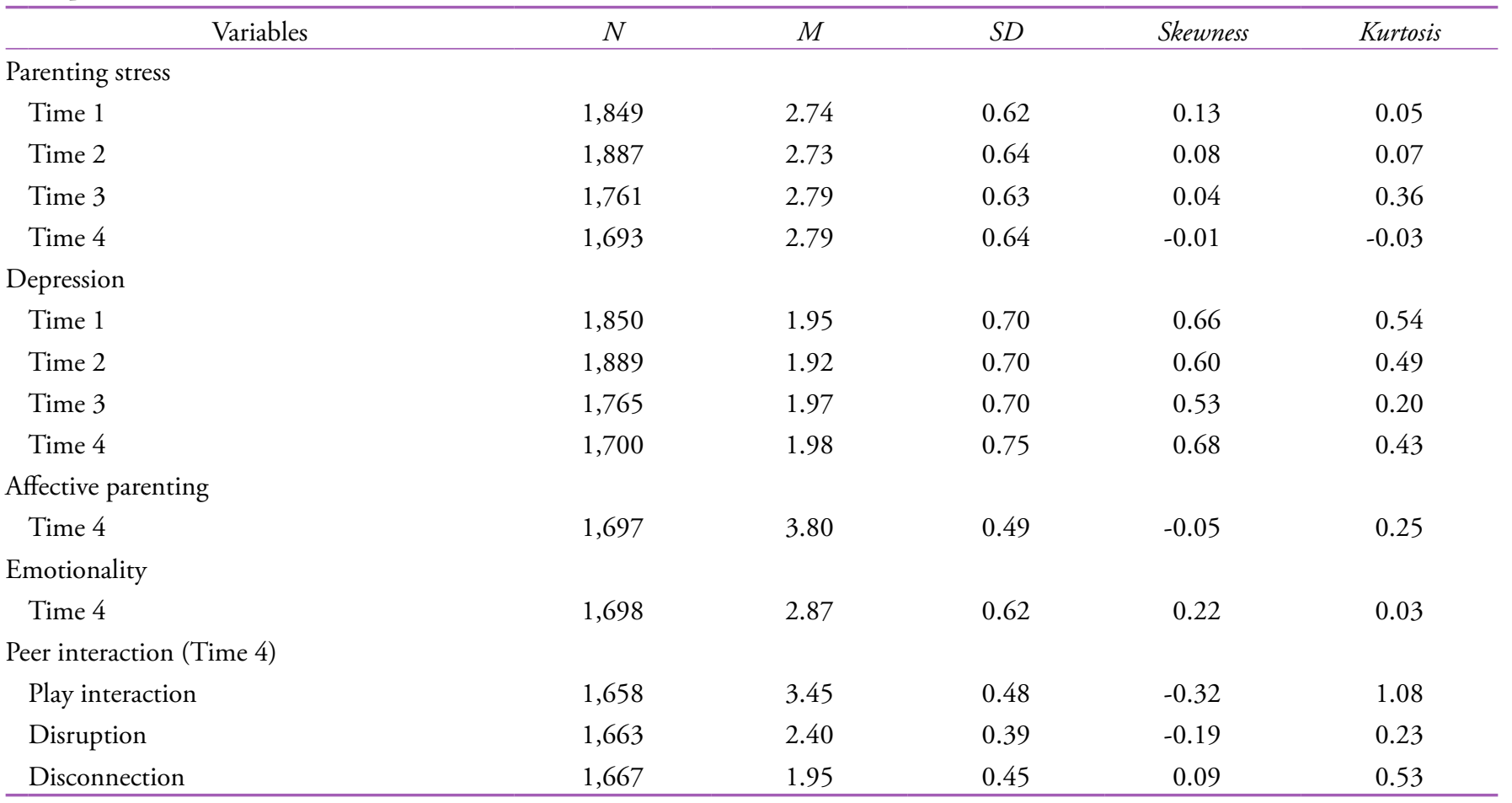

Note. All variables were scored by 5 -point Likert scale. 
Table 2

Descriptive Statistics by Maternal Employment Status

\begin{tabular}{|c|c|c|c|c|c|c|c|c|c|c|c|}
\hline Variables & \multicolumn{5}{|c|}{ Unmployed mother } & \multicolumn{5}{|c|}{ Employed mother } & $t$ \\
\hline \multicolumn{12}{|l|}{ Parenting stress } \\
\hline Time 2 & 1,298 & 2.76 & 0.64 & 0.12 & 0.16 & 537 & 2.64 & 0.62 & 0.04 & -0.17 & $3.73^{* * *}$ \\
\hline Time 3 & 1,202 & 2.82 & 0.64 & 0.02 & 0.50 & 501 & 2.72 & 0.62 & 0.10 & 0.00 & $2.89^{* *}$ \\
\hline \multicolumn{12}{|l|}{ Depression } \\
\hline Time 1 & 1,314 & 1.98 & 0.72 & 0.66 & 0.55 & 536 & 1.87 & 0.67 & 0.62 & 0.39 & $2.93^{* *}$ \\
\hline Time $2^{\mathrm{a}}$ & 1,300 & 1.94 & 0.72 & 0.62 & 0.56 & 538 & 1.85 & 0.66 & 0.61 & 0.43 & $2.50^{*}$ \\
\hline Time 3 & 1,203 & 1.98 & 0.71 & 0.53 & 0.24 & 504 & 1.94 & 0.67 & 0.48 & 0.11 & .98 \\
\hline Emotionality (Time 4) & 1,170 & 2.89 & 0.62 & 0.19 & -0.03 & 484 & 2.83 & 0.59 & 0.27 & 0.30 & 1.78 \\
\hline \multicolumn{12}{|l|}{ Peer interaction (Time 4) } \\
\hline Play interaction & 1,145 & 3.43 & 0.48 & -0.34 & 1.04 & 469 & 3.51 & 0.47 & -0.09 & 0.70 & $-3.05^{* *}$ \\
\hline Disruption & 1,147 & 2.40 & 0.39 & -0.23 & -0.01 & 472 & 2.37 & 0.38 & -0.42 & 0.22 & 1.50 \\
\hline Disconnection & 1,150 & 1.95 & 0.44 & -0.03 & 0.20 & 473 & 1.95 & 0.44 & 0.12 & 0.56 & -.29 \\
\hline
\end{tabular}

Note. ${ }^{\mathrm{E}}$ Equal variances not assumed.

${ }^{*} p<.05 .{ }^{* *} p<.01$. ${ }^{* * *} p<.001$.

학업 중으로 응답한 경우를 취업모로, 미취업/미학업으로 응 답한 경우를 전업모로 분류하여 분석에 이용하였다. 어머니의 출산 후 4년 간 양육스트레스는 전업모가 취업모보다 매년 더 높게 나타났으며, 이 차이는 모두 통계적으로 유의하였다. 우 울 또한 전업모가 취업모보다 매년 더 높게 느끼고 있는 것으 로 나타났으나, 이 차이는 자녀 연령이 만 1세 이하로 매우 어 린 시기에 해당하는 1 차(전업모: $M=1.98, S D=0.72$; 취업모: $M=1.87, S D=0.67$ ) 및 2차 연도(전업모: $M=1.94, S D=0.72$; 취업모: $M=1.85, S D=0.66$ )에만 통계적으로 유의하였다(1차: $t=2.93, p<.01 ; 2$ 차: $t=2.50, p<.05)$. 어머니의 온정적 양육 행동은 취업모 $(M=3.83, S D=0.51)$ 가 전업모 $(M=3.78, S D=$ 0.49)에 비해 약간 더 높은 것으로 나타났지만 통계적으로 유 의한 차이는 아니었다. 유아 관련 변인을 살펴보면, 전업모 $(M$ $=2.89, S D=0.62)$ 가 취업모 $(M=2.83, S D=0.59)$ 에 비해 자녀 의 부정적 정서표현을 약간 더 높게 평가하고 있었으나, 이 차 이는 통계적으로 유의하지 않았다. 유아 또래상호작용에서는 긍정적 놀이상호작용 하위영역에서만 유의한 차이 $(t=-3.05, p$ $<.01)$ 가 나타났는데, 취업모 $(M=3.51, S D=0.47)$ 가 전업모 $(M$
$=3.43, S D=0.48)$ 에 비해 자녀가 긍정적 놀이상호작용 특성을 더 많이 보이는 것으로 인식하고 있었다.

\section{양육스트레스 잠재성장모형}

\section{양육스트레스 변화의 무조건모형}

어머니의 출산 후 4 년 간 양육스트레스 변화 궤적을 살펴보기 위하여 잠재성장모형 무조건모형으로 무변화모형, 선형모형, 이차함수 모형을 설정하여 각각의 모형적합도를 비교하였다. 조사시점이 4 개 이상인 경우부터 성장요인을 3 개 포함하는 이차함수 모형을 검증할 수 있으므로, 이를 포함하여 각 모형 에 대한 적합도를 비교한 결과는 Table 3과 같다.

어머니의 양육스트레스 변화 궤적을 설명하는 가장 적합한 모형을 선택하기 위하여 $\chi^{2}, \mathrm{TLI}, \mathrm{CFI}, \mathrm{RMSEA}$ 값을 종합적으 로 살펴본 결과, 양육스트레스의 변화 궤적은 선형모형이 가 장 타당한 것으로 나타났다. 무변화모형은 모형적합도가 가 장 낮았으며, 이차함수 모형의 경우 변화율과 이차항의 추정 
Table 3

Comparisons of Latent Growth Model Fit of Parenting Stress

\begin{tabular}{lllcccccc}
\hline \multicolumn{1}{c}{ Model } & \multicolumn{1}{c}{ Factor } & & $\chi^{2}$ & $d f$ & $p$ & TLI & CFI & RMSEA (90\% CI) \\
\hline No change & Intercept & $2.757^{* * *}$ & 116.663 & 8 & .000 & .955 & .964 & $.080(.067 \sim .093)$ \\
Linear & Intercept & $2.732^{* * *}$ & 23.415 & 5 & .000 & .988 & .994 & $.041(.025 \sim .059)$ \\
& Slope & $0.018^{* * *}$ & & & & & & \\
Quadratic & Intercept & $2.739^{* * *}$ & 8.482 & 1 & .004 & .975 & .998 & $.059(.027 \sim .098)$ \\
& Slope & -0.001 & & & & & & \\
& Quadratic slope & 0.006 & & & & & & \\
\end{tabular}

${ }^{* * *} p<.001$.

치가 통계적으로 유의하지 않아 제외되었다. 최적 모형인 선 형모형은 성장요인의 추정치가 모두 유의하였으며 TLI, CFI 값이 1 에 가깝고 RMSEA 값이 .05 이하, $90 \%$ 신뢰구간의 상 한값 또한 .08 이하로 적합도가 매우 좋은 것으로 나타났다 $\left(\chi^{2}=23.415[d f=5, p<.001], \mathrm{TLI}=.988, \mathrm{CFI}=.994, \mathrm{RMSEA}=\right.$ .041). 선택된 모형은 Figure 2와 같으며, 모수 추정치는 Table 4 에 제시하였다.

출산 직후, 자녀가 만 0세일 때 어머니 양육스트레스의 초
기치는 5점 척도를 기준으로 2.732 이었으며 매년 .018씩 증가 하는 것으로 나타났다. 양육스트레스의 초기치와 변화율은 유 의한 부적 상관을 보여 $(r=-.255, p<.001)$ 양육스트레스 초기 치가 높을수록 느리게 증가함을 알 수 있었다. 양육스트레스 의 초기치와 변화율의 분산 또한 모두 유의하여 시간에 따른 변화 궤적에 개인차가 있음을 확인하였다.

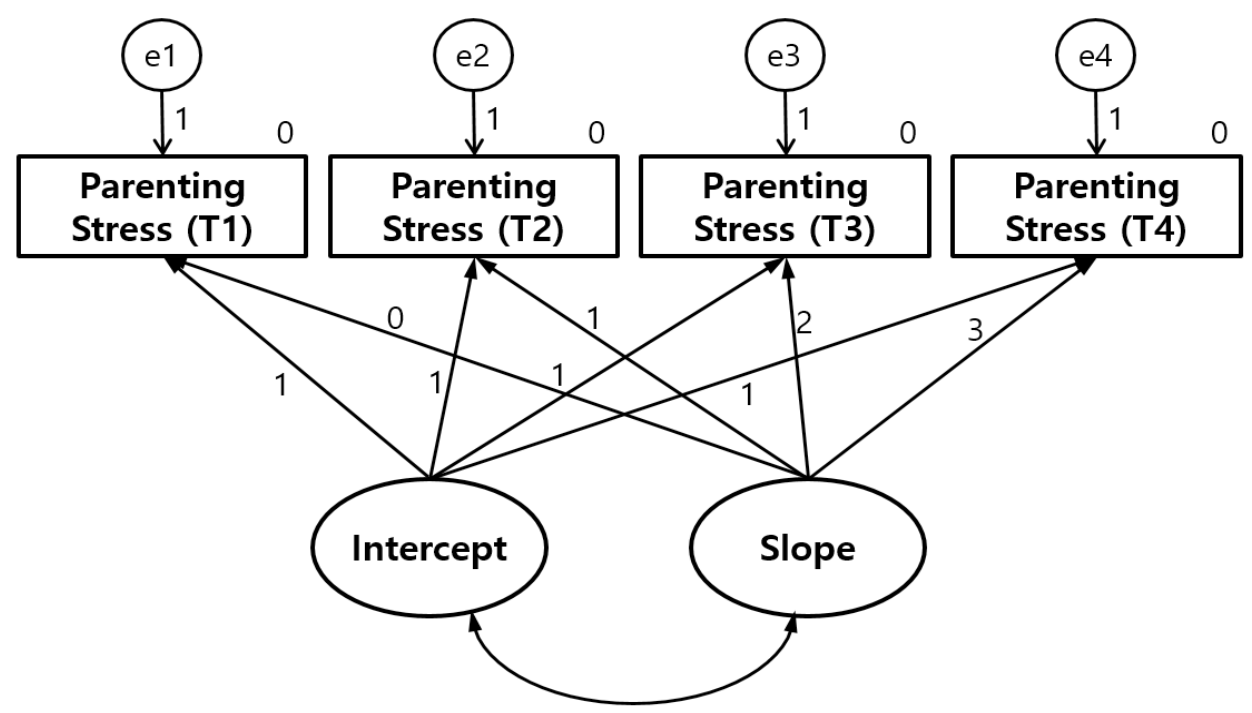

Figure 2. Latent growth model of parenting stress.

Table 4

Estimates of the Trajectory of Parenting Stress: Unconditional Model

\begin{tabular}{lccc}
\hline & Mean $(S E)$ & Variance $(S E)$ & Covariance $(r)$ \\
\hline Intercept & $2.732(.013)^{* * *}$ & $.259(.012)^{* * *}$ & $-.016(-.255)^{* * *}$ \\
Slope & $.018(.005)^{* * *}$ & $.015(.002)^{* * *}$ & \\
\hline
\end{tabular}

${ }^{* * *} p<.001$. 
각 시점의 우울을 통제한 양육스트레스 변화의 조건 모형

본 연구에서는 선행연구들의 결과를 근거로 하여 어머니 정서 적 건강의 주요 지표인 우울이 양육스트레스의 개인차에 영향 을 미칠 것으로 예측하였다. 앞서 기술통계에서도 확인된 바 와 같이, 한국아동패널조사에서 어머니의 우울은 시간에 따 라 변화하는 특성을 보였으므로 시간 가변성 공변량 모형을 적용하여 각 시점에서 어머니의 우울을 통제하는 조건모형을 Figure 3과 같이 설정하여 분석하고 모수 추정치를 Table 5에 제시하였다.

분석 결과, 우울을 통제한 조건모형의 모형적합도는 $\chi^{2}=$ $15.984(d f=9, p=.067), \mathrm{TLI}=.996, \mathrm{CFI}=.999, \mathrm{RMSEA}=.019$
(90\% CI $[.000, .034])$ 로 무조건모형에 비하여 모형적합도가 크게 향상된 것을 확인할 수 있었다. 우울을 통제한 경우에도 영아기 자녀를 키우는 어머니의 양육스트레스는 꾸준히 증가 하는 것으로 나타났다. 우울을 통제하지 않은 무조건모형과 비교하였을 때 출산 직후 양육스트레스는 2.241로 더 낮았으 나 증가율은 .060으로 더 높게 나타났다. 조건모형에서 양육 스트레스 초기치와 변화율은 부적 상관으로 $(r=-.200, p<.01)$, 무조건모형에서와 같이 초기치가 높을수록 천천히 증가하는 양상을 보였다. 초기치와 변화율의 분산 또한 모두 유의하여, 이 모형에도 개인차가 있음을 알 수 있었다. 각 시점에서 우울 이 양육스트레스에 미치는 영향력은 모두 유의수준 .001에서 유의하게 나타났으며, 우울이 높을수록 양육스트레스도 높게 지각하는 것으로 나타났다. 표준화계수를 통해 변인 간 영향

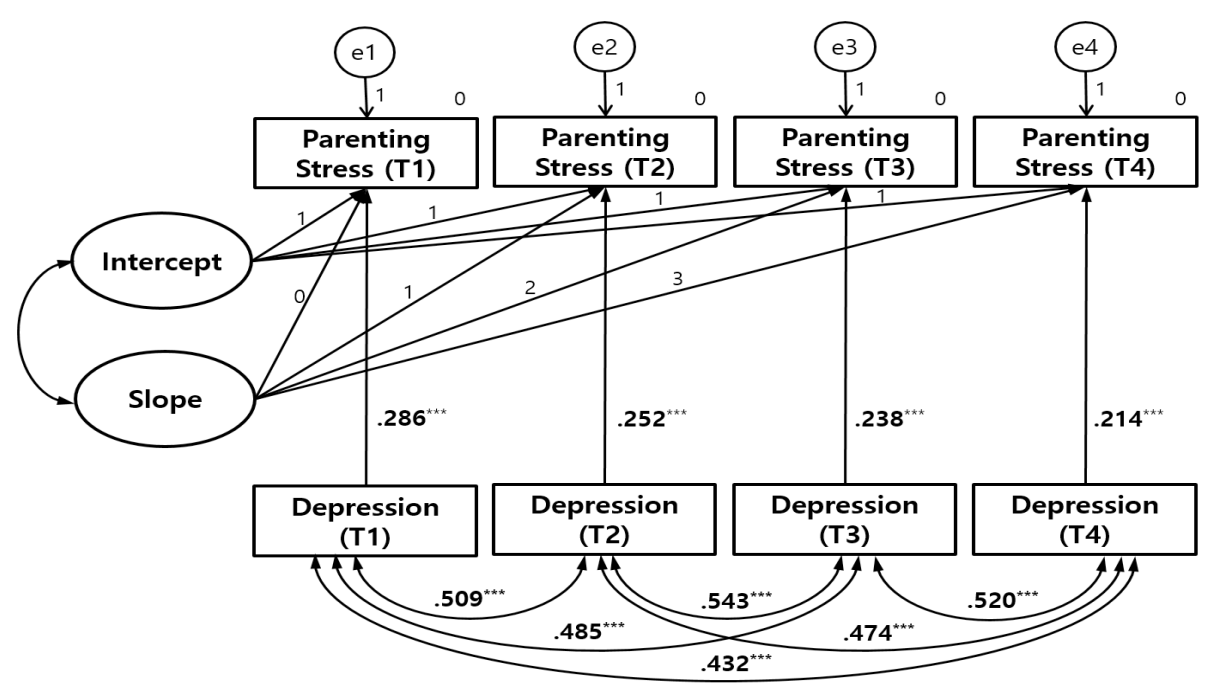

Figure 3. Trajectory of parenting stress: Conditional model controlled each year's depression. Figures in bold refer to standardized coefficients. Eight covariance paths between the intercept/slope variable and each year's depression were omitted due to the lack of space. ${ }^{* * *} p<.001$.

Table 5

Estimates of the Trajectory of Parenting Stress: Conditional Model

\begin{tabular}{lccc}
\hline & Mean $(S E)$ & Variance $(S E)$ & Covariance $(r)$ \\
\hline Intercept & $2.241(.047)^{* * *}$ & $.187(.011)^{* * *}$ & $-.009(-.200)^{* *}$ \\
Slope & $.060(.026)^{*}$ & $.012(.002)^{* * *}$ \\
\hline Path & $B(S E)$ & .286 \\
\hline Depression $\rightarrow$ Parenting stress (T1) & $.255(.024)^{* * *}$ & .252 \\
Depression $\rightarrow$ Parenting stress (T2) & $.224(.015)^{* * *}$ & .238 \\
Depression $\rightarrow$ Parenting stress (T3) & $.214(.014)^{* * *}$ & .214 \\
Depression $\rightarrow$ Parenting stress (T4) & $.184(.023)^{* * *}$ & \\
\hline
\end{tabular}

${ }^{*} p<.05 .{ }^{* *} p<.01 .{ }^{* * *} p<.001$. 
력의 정도를 비교해보면 1 차 $(\beta=.286, p<.001), 2$ 차 $(\beta=.252$, $p<.001), 3$ 차 $(\beta=.238, p<.001), 4$ 차 $(\beta=.214, p<.001)$ 연도순 으로 영향력이 큰 것으로 나타나, 자녀가 어릴수록 우울이 양 육스트레스에 더 큰 영향을 미치고 있었다.

\section{어머니 취업여부에 따른 다집단분석}

각 시점에서 우울을 통제하였을 때의 양육스트레스 변화 양상 이 어머니의 취업여부에 따라 차이가 있는지 확인하기 위하여 다집단분석(multiple group analysis)을 실시하였다. 기저모형의 모형적합도를 살펴본 결과, $\chi^{2}=20.010(d f=18, p=.332)$, TLI $=.999, \mathrm{CFI}=1.000, \mathrm{RMSEA}=.007(90 \% \mathrm{CI}[.000, .021])$ 로 모 형의 설명력이 매우 높은 것으로 나타났다. $\chi^{2}$ 검증의 유의확 률 또한 .05 이상으로 모형의 적합성이 확인되었다. 기저모형 을 통해 전업모와 취업모 집단 간 양육스트레스 변화 궤적의 추정치를 살펴보면 Table 6과 같다.

1 차 연도에서 4 차 연도까지 각 시점별로 우울이 양육스트 레스에 미치는 영향력은 전업모와 취업모 집단에서 모두 유의 하여, 우울 수준이 높을수록 양육스트레스도 높아지는 것을 알 수 있었다. 또한 두 집단 모두 우울이 양육스트레스에 미치 는 영향력은 출산 첫 해에 가장 높고, 시간이 흐를수록 그 영향 력이 감소하는 추세를 보였다. 우울을 통제하였을 때 전업모 의 양육스트레스 초기치 예측평균은 $2.272(p<.001)$, 변화율 의 예측평균은 $.065(p<.05)$ 로 모두 통계적으로 유의하여 전 업모의 경우 우울을 통제한 후에도 시간에 따라 양육스트레스 가 유의하게 증가하는 것으로 나타났다. 전업모의 양육스트레
스 초기치(.193, $p$ <.001)와 변화율( $.014, p<.001)$ 의 분산 또한 모두 유의하여, 우울을 통제한 후에도 전업모들 간 양육스트 레스 변화 궤적에는 개인차가 나타나는 것을 알 수 있었다. 반 면 취업모의 경우에는 초기치의 예측평균 $(2.164, p<.001)$ 및 분산(.168, $p$ <.001)만 유의한 것으로 나타나, 우울을 통제하였 을 때 취업모의 경우 시간에 따른 양육스트레스의 변화는 사 라지는 것으로 나타났다.

형태동일성 검증(기저모형)을 통하여 전업모와 취업모 집 단 간 양육스트레스 기울기에는 유의한 차이가 있음을 확인 하였고, 경로동일성 및 절편요인의 평균동일성 검증을 통하 여 각 시점에서 우울이 양육스트레스에 미치는 영향력 및 양 육스트레스 변화의 초기치에서 집단 간 차이가 유의하게 나 타나는지 분석한 결과를 Table 7에 제시하였다. 경로동일성 검증 결과, 제약모형의 모형적합도는 $\chi^{2}=23.280(d f=22, p=$ $.386), \mathrm{TLI}=.999, \mathrm{CFI}=1.000, \mathrm{RMSEA}=.005$ (90\% CI [.000, .019])로 매우 좋은 수준으로 나타났다. $\chi^{2}$ 차이 검증 결과 영가 설을 기각하지 못하여 $\left(\Delta \chi^{2}=3.27[\Delta d f=4, p<.05]\right)$, 각 시점 에서 우울이 양육스트레스에 미치는 영향력은 전업모와 취업 모 집단 간 유의한 차이가 없는 것으로 나타났다. 경로동일성 모형이 채택되었으므로 이에 대하여 양육스트레스의 초기치 를 제약한 평균동일성 모형을 검증한 결과, 제약모형의 모형 적합도는 $\chi^{2}=31.410(d f=23, p=.113), \mathrm{TLI}=.996, \mathrm{CFI}=.999$, $\mathrm{RMSEA}=.013(90 \% \mathrm{CI}[.000, .024])$ 으로 매우 높았다. $\chi^{2}$ 차이 검증 결과 영가설을 기각하여 $\left(\Delta \chi^{2}=8.13[\Delta d f=1, p<.05]\right)$, 양육스트레스의 초기치는 전업모가 취업모보다 유의하게 높 은 것으로 나타났다. 요약하면, 매 시점에서 우울이 양육스트

Table 6

Estimates of the Conditional Model by Maternal Employment Status

\begin{tabular}{|c|c|c|c|c|}
\hline \multirow[b]{2}{*}{ Parameter } & \multicolumn{2}{|c|}{$\begin{array}{l}\text { Unemployed mother } \\
\qquad(n=1,453)\end{array}$} & \multicolumn{2}{|c|}{$\begin{array}{l}\text { Employed mother } \\
\qquad(n=625)\end{array}$} \\
\hline & & & & \\
\hline Mean of intercept $(S E)$ & \multicolumn{2}{|c|}{$2.272(.056)^{* * *}$} & \multicolumn{2}{|c|}{$2.164(.089)^{* * *}$} \\
\hline Mean of slope $(S E)$ & \multicolumn{2}{|c|}{$.065(.031)^{*}$} & \multicolumn{2}{|c|}{$.045(.048)$} \\
\hline Variance of intercept $(S E)$ & \multicolumn{2}{|c|}{$.193(.013)^{* * *}$} & \multicolumn{2}{|c|}{$.168(.020)^{* * *}$} \\
\hline Variance of slope $(S E)$ & \multicolumn{2}{|c|}{$.014(.002)^{* * *}$} & \multicolumn{2}{|c|}{$.005(.003)$} \\
\hline Covariance $(r):$ Intercept $\leftrightarrow$ Slope & \multicolumn{2}{|c|}{$-.013(-.250)^{* *}$} & \multicolumn{2}{|c|}{$.002(.058)$} \\
\hline Path & $B(S E)$ & $\beta$ & $B(S E)$ & $\beta$ \\
\hline Depression $\rightarrow$ Parenting stress (T1) & $.247(.027)^{* * *}$ & .285 & $.274(.046)^{* * *}$ & .286 \\
\hline Depression $\rightarrow$ Parenting stress (T2) & $.219(.017)^{* * *}$ & .251 & $.233(.029)^{* * *}$ & .252 \\
\hline Depression $\rightarrow$ Parenting stress (T3) & $.207(.017)^{* * *}$ & .231 & $.234(.028)^{* * *}$ & .255 \\
\hline Depression $\rightarrow$ Parenting stress (T4) & $.173(.027)^{* * *}$ & .204 & $.215(.045)^{* * *}$ & .243 \\
\hline
\end{tabular}

${ }^{*} p<.05 .{ }^{* *} p<.01 .{ }^{* * *} p<.001$. 
Table 7

Invariance Testing of the Conditional Model by Maternal Employment Status

\begin{tabular}{|c|c|c|c|c|c|c|c|c|}
\hline Model & $\chi^{2}$ & $d f$ & $p$ & TLI & CFI & $\begin{array}{l}\text { RMSEA } \\
(90 \% \mathrm{CI})\end{array}$ & $\Delta \chi^{2}$ & $\Delta d f$ \\
\hline $\begin{array}{l}\text { Configural invariance } \\
\text { (unconstrained model) }\end{array}$ & 20.010 & 18 & .332 & .999 & 1.000 & $\begin{array}{c}.007 \\
(.000 \sim .021)\end{array}$ & & \\
\hline Path coefficient invariance & 23.280 & 22 & .386 & 999 & 1.000 & $\begin{array}{c}.005 \\
(.000 \sim .019)\end{array}$ & 3.27 & 4 \\
\hline Intercept invariance & 31.410 & 23 & .113 & .996 & .999 & $\begin{array}{c}.013 \\
(.000 \sim .024)\end{array}$ & 8.13 & 1 \\
\hline
\end{tabular}

Note. Chi-square test at the .05 level of significance.

레스에 미치는 영향력은 전업모와 취업모 집단 간 동일하였 다. 또한 우울을 통제하였을 때 양육스트레스 변화 양상은 전 업모가 취업모보다 초기치가 유의하게 더 높았으며, 취업모의 양육스트레스는 시간에 따른 변화가 나타나지 않은 반면 전업 모의 양육스트레스는 시간에 따라 유의하게 증가하는 것으로 나타났다.

\section{양육스트레스 변화 궤적이 온정적 양육행동 및 유아 사회정서발달에 미치는 영향에 대한 구조 모형}

\section{구조 모형 분석}

선행연구에 따라 영아기 자녀를 키우는 어머니의 우울을 통 제한 양육스트레스 변화 궤적, 온정적 양육행동 및 유아 사 회정서발달 간의 인과관계를 설정한 구조 모형의 모형적합 도는 $\chi^{2}=1,288.900(d f=255, p<.001), \mathrm{TLI}=.921, \mathrm{CFI}=.938$, $\mathrm{RMSEA}=.043(90 \% \mathrm{CI}[.041, .046])$ 으로 양호한 수준으로 나 타나 연구모형이 실제 데이터를 타당하게 설명하고 있는 것을 확인하였다. 분석 결과를 Figure 4에 제시하였다.

변인들 간 영향력의 경로 및 모수 추정치는 Table 8에 구체 적으로 제시하였다. 각 시점에서 우울이 양육스트레스에 미치 는 영향력은 모두 유의하였으며 영향력의 정도는 매년 감소하 였다. 이 때 어머니의 양육스트레스 변화 궤적은 첫 시점에서 2.142 이고 매년 .135씩 유의하게 증가하였으며 변화 궤적에는 개인차가 있는 것으로 나타났다(초기치 분산 $=.173, p<.001$; 변화율 분산 $=.011, p<.001)$. 양육스트레스의 증가는 4 차 연 도 어머니의 온정적 양육행동의 초기치 $(\beta=-.435, p<.001)$ 와 변화율 $(\beta=-.560, p<.001)$ 에 모두 유의한 부적 영향을 미치고 있었다. 즉 어머니의 우울을 통제하였을 때, 출산 직후 양육스
트레스가 높고 매년 더 빨리 증가할수록 이후 유아에 대하여 온정적이고 반응적인 양육행동을 덜 보였다. 또한 양육스트레 스 초기치 $(\beta=.257, p<.001)$ 와 변화율 $(\beta=.482, p<.001)$ 모두 유아의 부정적 정서성에 대한 어머니의 평가에 정적인 영향을 미치고 있었으며, 유아의 또래상호작용에는 양육스트레스 초 기치 $(\beta=-.099, p<.01)$ 와 변화율 $(\beta=-.228, p<.001)$ 모두 부적 인 영향을 미치는 것으로 나타났다. 즉 어머니의 우울을 통제 하였을 때, 출산 직후 양육스트레스가 높고 매년 더 빨리 증가 할수록 어머니는 유아의 부정적 정서를 높게 인식하였으며 유 아가 긍정적 또래상호작용을 덜 보이는 것으로 나타났다. 어 머니의 온정적 양육은 유아의 정서성에는 유의한 영향을 미치 지 않았으나, 또래상호작용에는 정적인 영향력을 미치고 있었 다 $(\beta=.196, p<.001)$. 즉 어머니가 온정적이고 반응적인 양육 행동을 보일수록 유아는 더욱 긍정적인 또래상호작용 행동을 보인다고 할 수 있다. 위의 결과를 종합하면 어머니의 우울을 통제하였을 때 영아 자녀를 키우는 동안 양육스트레스 변화 궤적은 유아의 정서성에 직접적으로, 그리고 온정적 양육행동 을 통해서 간접적으로 유아의 또래상호작용에 영향을 미치고 있음을 알 수 있다. 동일한 시점에서 유아의 정서성이 또래상 호작용에 미치는 영향력 또한 유의하여 $(\beta=-.262, p<.001)$, 유 아의 부정적 정서 표현이 높을수록 긍정적 또래상호작용이 낮 아지는 것을 확인할 수 있었다.

\section{어머니 취업여부에 따른 다집단분석}

구조모형의 변인들 간 영향력이 어머니의 취업여부에 따라 차 이가 있는지 알아보기 위하여 다집단분석을 위한 모형동일성 검증을 실시한 결과를 Table 9에 제시하였다.

형태동일성 검증을 위하여 기저모형의 모형적합도를 살 펴본 결과, $\chi^{2}=1,534.731(d f=510, p<.001), \mathrm{TLI}=.920, \mathrm{CFI}$ 


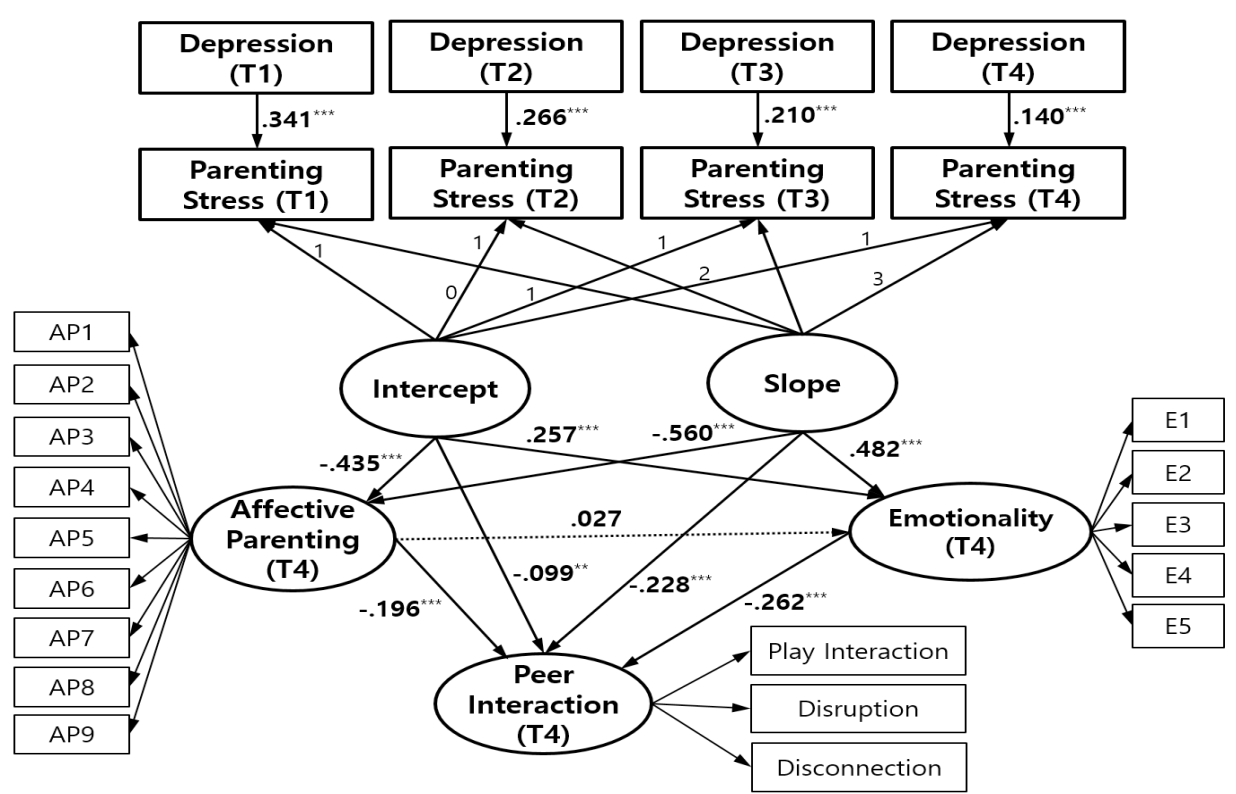

Figure 4. Structural model: Effects of parenting stress trajectory on affective parenting and the socioemotional development of preschoolers. Statistically significant paths are indicated by a solid line. Figures in bold refer to standardized regression coefficients. Covariance paths and error terms were omitted due to the lack of space.

${ }^{* *} p<.01 .{ }^{* * *} p<.001$

Table 8

Estimates of the Structural Model: Effects of Parenting Stress Trajectory on Affective Parenting and Socioemotional Development of Preschoolers

\begin{tabular}{|c|c|c|c|c|}
\hline & & $B$ & $S E$ & $\beta$ \\
\hline \multicolumn{5}{|l|}{ Path } \\
\hline Intercept of parenting stress & $\rightarrow \quad$ Affective parenting (T4) & $-.446^{* * *}$ & .035 & -.435 \\
\hline Slope of parenting stress & $\rightarrow \quad$ Affective parenting (T4) & $-2.234^{* * *}$ & .236 & -.560 \\
\hline Intercept of parenting stress & $\rightarrow$ Emotionality (T4) & $.416^{* * *}$ & .065 & .257 \\
\hline Slope of parenting stress & $\rightarrow \quad$ Emotionality (T4) & $3.030^{* * *}$ & .491 & .482 \\
\hline Intercept of parenting stress & $\rightarrow \quad$ Peer interaction (T4) & $-.055^{* *}$ & .021 & -.099 \\
\hline Slope of parenting stress & $\rightarrow \quad$ Peer interaction (T4) & $-.499^{* * *}$ & .151 & -.228 \\
\hline Affective parenting (T4) & $\rightarrow$ Emotionality (T4) & .042 & .083 & .027 \\
\hline Affective parenting (T4) & $\rightarrow \quad$ Peer interaction (T4) & $.107^{* * *}$ & .026 & .196 \\
\hline Emotionality (T4) & $\rightarrow \quad$ Peer interaction (T4) & $-.091^{* * *}$ & .015 & -.262 \\
\hline Depression (T1) & $\rightarrow \quad$ Parenting stress (T1) & $.305^{* * *}$ & .020 & .341 \\
\hline Depression (T2) & $\rightarrow \quad$ Parenting stress (T2) & $.236^{* * *}$ & .013 & .266 \\
\hline Depression (T3) & $\rightarrow \quad$ Parenting stress (T3) & $.189^{* * *}$ & .013 & .210 \\
\hline Depression (T4) & $\rightarrow \quad$ Parenting stress (T4) & $.119^{* * *}$ & .019 & .140 \\
\hline \multicolumn{5}{|l|}{ Parameter } \\
\hline \multicolumn{2}{|c|}{ Mean: Intercept of parenting stress } & $2.142^{* * *}$ & .040 & \\
\hline \multicolumn{2}{|c|}{ Mean: Slope of parenting stress } & $.135^{* * *}$ & .021 & \\
\hline \multicolumn{2}{|c|}{ Variance: Intercept of parenting stress } & $.173^{* * *}$ & .010 & \\
\hline \multicolumn{2}{|c|}{ Variance: Slope of parenting stress } & $.011^{* * *}$ & .002 & \\
\hline \multicolumn{2}{|c|}{ Covariance (Intercept $\leftrightarrow$ Slope) } & -.004 & .003 & -.099 \\
\hline
\end{tabular}

${ }^{* *} p<.01 .{ }^{* * *} p<.001$. 
Table 9

Invariance Testing of the Structural Model by Maternal Employment Status

\begin{tabular}{|c|c|c|c|c|c|c|c|c|}
\hline Model & $\chi^{2}$ & $d f$ & $p$ & TLI & CFI & $\begin{array}{l}\text { RMSEA } \\
(90 \% \mathrm{CI})\end{array}$ & $\Delta \chi^{2}$ & $\Delta d f$ \\
\hline $\begin{array}{l}\text { Configural invariance } \\
\text { (unconstrained model) }\end{array}$ & $1,534.731$ & 510 & .000 & .920 & .937 & $\begin{array}{c}.031 \\
(.029 \sim .033)\end{array}$ & & \\
\hline Metric invariance & $1,548.859$ & 524 & .000 & .922 & .937 & $\begin{array}{c}.031 \\
(.029 \sim .032)\end{array}$ & 14.128 & 14 \\
\hline Path coefficient invariance & $1,581.248$ & 537 & .000 & .923 & .936 & $\begin{array}{c}.031 \\
(.029 \sim .032)\end{array}$ & 32.389 & 13 \\
\hline
\end{tabular}

Note. Chi-square test at the .05 level of significance.

$=.937, \mathrm{RMSEA}=.031(90 \%$ CI $[.029, .033])$ 로 모형적합도 가 좋은 것으로 나타났다. 즉, 이 구조모형은 전업모와 취업 모 집단 모두를 잘 설명하는 타당한 모형임을 확인하였다. 다 음으로 측정도구의 요인적재치를 동일하게 제약한 측정동일 성 모형을 검증하였다. 측정동일성 모형의 모형적합도는 $\chi^{2}=$ $1,548.859(d f=524, p<.001), \mathrm{TLI}=.922$, CFI = .937, RMSEA $=.031(90 \% \mathrm{CI}[.029, .032])$ 로 좋은 수준이었다. 기저모형과의 $\chi^{2}$ 차이 검증 결과, 두 모형이 통계적으로 동일한 것으로 나타 나 $\left(\Delta \chi^{2}=14.13[\Delta d f=14, p<.05]\right)$ 더욱 간명한 측정동일성 모 형이 채택되었다. 즉, 전업모와 취업모 집단 모두 잠재변인들 의 측정도구를 동일하게 인식하고 있는 것으로 나타났다. 측 정동일성이 확보되어 경로동일성 검증을 실시하였다. 변인 간 경로를 모두 제약한 모형의 적합도는 $\chi^{2}=1581.248(d f=537$, $p<.001), \mathrm{TLI}=.923, \mathrm{CFI}=.936, \mathrm{RMSEA}=.031$ (90\% CI [.029, .032])로 좋은 적합도를 보였다. 기저모형과의 $\chi^{2}$ 차이 검증 결 과 유의수준 .05에서 영가설을 기각하여 $\left(\Delta \chi^{2}=32.39[\Delta d f=13\right.$, $p<.05])$, 전업모와 취업모 간 변인들의 영향력의 경로는 서로 다른 것으로 나타났다. 최종 채택된 측정동일성 모형에 대하 여 어머니의 취업여부에 따른 다집단분석 결과를 Table 10 에 제시하였다.

측정동일성 모형이 최종 모형으로 채택되었으므로 집단 간 교차타당성이 인정되어 회귀계수의 비교가 가능하였다. 매년 우울이 양육스트레스에 미치는 영향력은 전업모와 취업모 모 두 각 시점에서 유의하였으며, 영향력의 정도는 시간이 흐를 수록 감소하는 추세를 보였다.

구조모형에서 각 변인들 간 영향력은 전업모와 취업모 간 큰 차이를 보였는데, 전업모의 경우 전체 어머니를 대상으로 한 구조모형 분석 결과와 마찬가지로, 4 차 연도의 온정적 양육 행동이 유아의 정서성에 미치는 영향력의 경로만 제외하고 모 든 경로가 유의한 것으로 나타났다. 구조모형에서 우울을 통
제하였을 때 영아 자녀를 키우는 동안 전업모의 양육스트레 스 초기치는 2.206 ( $p$ < .001)이고 매년 .128 ( $p<.001)$ 씩 증가 하였으며 변화 궤적에는 개인차가 존재하였다(초기치 분산 = $.186, p<.001$; 변화율 분산 $=.016, p<.001)$. 이러한 양육스트 레스의 증가 양상은 만 3 세 때 자녀의 부정적 정서표현 증가 (초기치: $B=.479, p<.001$; 변화율: $B=2.005, p<.001$ ) 및 긍정 적 또래상호작용 감소(초기치: $B=-.053, p<.05$; 변화율: $B=$ -.362, $p<.01)$ 에 직접 영향을 미침과 동시에, 온정적 양육행동 에 부정적 영향을 미침으로써(초기치: $B=-.444, p<.001$; 변화 율: $B=-1.843, p<.001)$ 이를 매개로 자녀의 긍정적 또래상호 작용을 감소시키는 간접적인 영향력을 갖는 것으로 나타났다 $(B=.137, p<.001)$. 반면 이 모형에서 취업모의 양육스트레스 초기치는 $2.042(p<.001)$ 이었고 매년 .115 ( $p<.01)$ 씩 증가하 는 것으로 나타났지만 양육스트레스의 증가가 유아 자녀의 부 정적 정서성이나 긍정적 또래상호작용에 미치는 직접 및 간접 영향력은 모두 유의하지 않았다. 다만 취업모의 양육스트레스 가 더 빨리 증가할수록 유아 자녀에 대한 온정적 양육행동이 감소하는 것으로 나타났으나 $(B=-5.125, p<.05)$, 변화율의 분 산이 유의하지 않았으므로(변화율 분산 $=.003, p=.110)$ 이 결 과는 해석의 의미가 없다고 볼 수 있다.

\section{논의 및 결론}

본 연구에서는 어머니의 정서적 건강이 양육행동 및 유아의 사회정서발달에 영향을 미친다는 선행연구 결과를 토대로 하 여, 어머니 정서적 건강의 주요 지표인 양육스트레스와 우울 의 변화를 중심으로 한 구조모형을 설정하여 분석하였다. 각 시점에서 우울을 통제하였을 때 만 0-3세 영아기 자녀를 키우 는 동안 어머니의 양육스트레스 변화 궤적을 살펴보고 이를 
Table 10

Multiple Group Analysis of the Structural Model by Maternal Employment Status

\begin{tabular}{|c|c|c|c|c|c|c|c|}
\hline & & \multicolumn{3}{|c|}{$\begin{array}{l}\text { Unemployed mother } \\
\quad(n=1,453)\end{array}$} & \multicolumn{3}{|c|}{$\begin{array}{l}\text { Employed mother } \\
\qquad(n=625)\end{array}$} \\
\hline & & $B$ & $S E$ & $\beta$ & $B$ & $S E$ & $\beta$ \\
\hline Intercept of parenting stress & $\rightarrow$ Affective parenting (T4) & $-.444^{* * *}$ & .037 & -.455 & -.297 & .182 & -.269 \\
\hline Slope of parenting stress & $\rightarrow$ Affective parenting (T4) & $-1.843^{* * *}$ & .187 & -.557 & $-5.125^{*}$ & 2.601 & -.691 \\
\hline Intercept of parenting stress & $\rightarrow$ Peer interaction (T4) & $-.053^{*}$ & .025 & -.094 & -.116 & .227 & -.185 \\
\hline Slope of parenting stress & $\rightarrow$ Peer interaction (T4) & $-.362^{* *}$ & .123 & -.192 & -5.390 & 16.790 & -1.280 \\
\hline Affective parenting (T4) & $\rightarrow$ Emotionality (T4) & -.087 & .084 & -.053 & 1.039 & 1.326 & .702 \\
\hline Affective parenting (T4) & $\rightarrow$ Peer interaction (T4) & $.137^{* * *}$ & .029 & .240 & -.302 & 1.388 & -.532 \\
\hline Depression (T3) & $\rightarrow$ Parenting stress (T3) & $.178^{* * *}$ & .015 & .197 & $.227^{* * *}$ & .026 & .247 \\
\hline Depression (T4) & $\rightarrow$ Parenting stress (T4) & $.110^{* * *}$ & .022 & .131 & $.171^{* * *}$ & .041 & .193 \\
\hline \multicolumn{8}{|c|}{ Parameter } \\
\hline \multicolumn{2}{|c|}{ Mean: Intercept of parenting stress } & $2.206^{* * *}$ & .050 & & $2.042^{* * *}$ & .068 & \\
\hline \multicolumn{2}{|c|}{ Mean: Slope of parenting stress } & $.128^{* * *}$ & .025 & & $.115^{* *}$ & .040 & \\
\hline \multicolumn{2}{|c|}{ Variance: Intercept of parenting stress } & $.186^{* * *}$ & .012 & & $.154^{* * *}$ & .017 & \\
\hline \multicolumn{2}{|c|}{ Variance: Slope of parenting stress } & $.016^{* * *}$ & .002 & & .003 & .002 & \\
\hline \multicolumn{2}{|c|}{ Covariance (Intercept $\leftrightarrow$ Slope) } & $-.011^{* *}$ & .004 & -.201 & .006 & .004 & .264 \\
\hline
\end{tabular}

${ }^{*} p<.05 .{ }^{* *} p<.01 .{ }^{* * *} p<.001$.

어머니 취업여부에 따라 비교하였다. 또한 우울을 통제하였을 때의 양육스트레스 변화가 만 3세 때 어머니의 온정적 양육행 동 및 유아의 사회정서발달(정서성, 또래상호작용)에 어떠한 영향을 미치는지, 영향력의 경로가 취업여부에 따라 어떻게 다른지 알아보기 위하여 구조모형을 설정하여 검증하였다. 본 연구의 주요 결과를 종합하여 논의를 이끌어내면 다음과 같다.

첫째, 양육스트레스 잠재성장모형 무조건모형 분석을 통해 살펴본 출산 직후부터 자녀가 만 3 세가 될 때까지 어머니의 양 육스트레스 변화 궤적은 선형 모형으로, 어머니의 양육스트 레스는 매년 꾸준히 증가하는 것으로 나타났다. 이는 4 개 연 도 패널자료를 종단 분석한 국내 선행연구들과 일치하는 결과 이며, 양육스트레스 변화 궤적에 개인차가 존재하였으므로 본 연구에서는 매년 변화하는 우울 수준을 통제 변인으로 하여 분석을 진행하였다.

둘째, 각 시점에서 우울을 통제한 양육스트레스 잠재성장 모형 조건모형을 분석한 결과, 각 시점에서 어머니의 우울이
양육스트레스에 미치는 영향력은 모두 유의하였으며 우울을 통제한 후에도 양육스트레스는 매년 증가하고 있는 것으로 나 타났다. 조건모형에서의 양육스트레스 변화 궤적을 무조건 모형과 비교하였을 때 초기치는 더 낮아졌지만(무조건모형: 2.732; 조건모형: 2.241) 증가율은 더 높아진 것으로 나타나(무 조건모형: .018; 조건모형: .060), 시간에 따른 양육스트레스의 변화를 더욱 명확하게 보여주었다. 즉, 출산 초기에는 산후우 울로 진단받지 않더라도 어머니의 전반적 우울과 같은 개인의 정서적 건강의 질이 자녀 양육을 더 부담스럽게 느끼는 것에 큰 영향력을 미치는 것을 의미하며, 시간이 흐를수록 자녀 양 육의 실제와 직접 관련된 다양한 요인들이 양육스트레스가 더 큰 폭으로 증가하는 데 영향을 미치고 있는 것으로 해석할 수 있다. 또한 신생아를 돌보는 어머니는 출산 전과 비교하여 양 육으로 인한 신체적 피로감과 부모됨에 적응하는 과정에서의 스트레스가 급격히 높아질 수 있는 시기이므로(Kwon, 2011), 출산 초기의 양육스트레스는 우울감과 더욱 밀접한 관련이 있 
을 것으로 예측할 수 있다. 그러나 시간이 흐를수록 영아기 자 녀를 돌보는 어머니의 양육스트레스는 우울과 같은 개인의 정 서적 문제와는 별개로 다루어질 필요가 있으며, 양육스트레스 의 증가에 영향을 미치는 다양한 외부적 요인에 대한 관심과 개입이 필요함을 시사한다.

셋째, 조건모형에 대한 다집단분석 결과, 전업모의 양육스 트레스 초기치가 취업모에 비해 더 높았으며 전업모의 경우에 만 시간에 따른 양육스트레스의 증가가 유의한 것으로 나타났 다. 이는 전업모와 취업모의 양육스트레스를 횡단적으로 비교 하였을 때 전업모의 양육스트레스가 더 높았다고 보고한 국 내 선행연구들과 일치하는 결과이다(Kwon, 2011; Sohn, 2012; Song et al., 2014). 또한 영유아기 어머니 양육스트레스 변화의 무조건모형에서 전업모의 양육스트레스는 시간에 따라 유의 하게 증가한 반면 취업모의 양육스트레스 변화는 유의하지 않 았던 종단분석 결과와도 일치한다(S. Park et al., 2015). 본 연구 에서는 각 시점의 우울을 통제한 경우에도 동일한 경향이 나 타나는 것을 확인함으로써 어머니 취업여부에 따른 양육스트 레스의 변화 궤적의 차이를 더욱 명확히 드러냈다고 볼 수 있 다.

이러한 결과는 영아 자녀를 키우며 전업모와 취업모가 경 험하는 정서적 건강 및 양육스트레스의 특성이 서로 다르다는 점을 시사한다. 영아 자녀를 키우는 취업모의 경우 우울을 통 제하였을 때 출산 직후 양육스트레스가 전업모에 비해 유의하 게 낮았고, 자녀의 연령이 증가하여도 양육스트레스가 증가하 지 않았다. 취업모는 일과 양육을 병행함으로써 양육에 투자 하는 절대적 시간이 적으며 전업모에 비해 돌봄과 관련된 사 회적 관계망을 활용할 수 있는 가능성 또한 더 높으므로(Y. Lee $\&$ Chin, 2013), 자녀 양육 과정에서 경험하는 실제적인 어려 움보다는 전반적 우울감이 자녀 양육을 힘든 것으로 인식하는 데 더 큰 영향을 미친다고 해석할 수 있다. 취업모가 느끼는 양 육스트레스의 증가는 어머니의 정서적 건강과 더욱 밀접한 관 련이 있으며, 출산 전후 어머니의 우울감에 대처하고 일과 양 육의 균형을 이룰 수 있도록 돕는 적절한 개입이 이루어진다 면 영아기 자녀를 키우는 동안의 양육스트레스 또한 중간 이 하(초기치: 2.164) 수준으로 유지할 수 있다는 점을 시사한다.

반면, 전업모의 경우 각 시점에서 취업모보다 높았던 우울 수준을 통제한 후에도 출산 직후의 양육스트레스가 취업모보 다 더 높고 지속적으로 증가한다는 점은 주목할 만한 결과이 다. 즉, 영아 자녀를 키우는 어머니는 일과 양육을 병행해야 하 는 것에서 느끼는 곤란함보다 양육을 전담하면서 느끼는 실질 적인 스트레스가 더욱 과중하다는 것으로 해석할 수 있다. 그
리고 전업모의 양육스트레스는 취업모에 비해 다양한 변인과 관련되어 있을 가능성이 있고, 단순히 피로나 노동 강도에서 비롯되는 일시적인 것이라기보다는 장기적으로 누적되는 특 성이 있음을 알 수 있다. 이는 영유아 자녀를 양육하는 어머니 의 경우 하루 양육 시간이 6시간 미만일 때 더 행복감을 느끼 며, 양육시간이 길수록 더 많은 휴식 시간을 원하는 것으로 나 타난 최근 조사결과와도 맥락을 같이 한다(Kwon, Choi, Kim, $\mathrm{Kim}, \& \mathrm{Lim}, 2016)$. 국외 선행연구들에서는 자녀가 유아기에 접어들면서 양육스트레스가 안정적인 추세를 보였던 것과 달 리(Mulsow et al., 2002; Williford et al., 2007), 국내 종단연구들 은 영유아기 동안의 지속적인 증가추세를 보고하였으며 본 연 구는 이러한 증가 양상이 우울을 통제하였을 때에도 전업모 집단에서만 유의하게 나타남을 밝혔다. 다집단분석을 통해 나 타난 두 집단 간의 뚜렷한 차이는 우리나라의 경우 어머니의 취업여부에 따라 양육 상황 및 활용 가능한 자원에 상당한 격 차가 존재하고 있음을 시사해준다. 이 격차는 양육스트레스의 변화 양상에 미치는 영향력이 크므로 추후 관련된 예측변인들 에 대한 연구가 보완되어야 하며 사회적 - 정책적 차원의 논의 가 요구된다고 할 수 있다.

각 시점에서 우울이 양육스트레스에 미치는 영향력에는 집 단 간 유의한 차이가 없었고, 전업모와 취업모 집단 모두 출산 첫 해에 우울이 양육스트레스에 미치는 영향력이 가장 크게 나타났으며 시간이 흐를수록 그 영향력이 점점 감소하는 추세 를 보였다. 두 집단 모두 출산 첫 해의 우울 수준이 가장 높았 던 것은 아니었지만 양육스트레스에 미치는 영향은 가장 큰 것으로 나타나, 이 시기의 우울감은 특히 자녀 양육과의 관련 성이 높다는 것을 알 수 있었다. 이를 통해 취업여부에 관계없 이 출산 직후 어머니의 우울감에 대한 정서적 지원 및 양육부 담을 줄일 수 있는 실질적인 도움이 필요함을 확인하였다.

넷째, 우울을 통제하였을 때 출산 후 4년 간 어머니 양육스 트레스의 변화 궤적은 이후 자녀가 만 3세가 되었을 때 부정 적 정서표현 증가 및 긍정적 또래상호작용 감소에 직접 영향 을 미쳤으며, 유아기 온정적 양육행동의 감소를 통해 자녀의 긍정적 또래 상호작용 감소에 간접적으로도 영향을 미치는 것 으로 나타났다. 이러한 결과는 양육스트레스가 유아의 사회 정서발달에 미치는 직접 효과(Anthony et al., 2005; Crnic et al., 2005) 및 간접 효과(Abidin, 1992; Deater-Deckard, 1998)를 모 두 확인한 결과라고 할 수 있다. 양육스트레스의 증가가 유아 사회정서발달의 두 변인에 미치는 영향력의 경로에 차이가 나 타났는데, 먼저 유아의 부정적 정서표현을 의미하는 정서성은 양육스트레스와 상관관계가 높았을 뿐 아니라 양육스트레스 
의 증가에 영향을 미치는 주요 변인이므로(Kwon, 2011) 양육 스트레스 수준이 높을수록 어머니들이 자녀의 정서성을 더 높 게 지각했을 가능성이 있다. 또한 긍정적 또래상호작용은 놀 이상황에서 나타나는 유아의 친사회성 및 정서표현 등 사회 적 관계에서 나타나는 행동특성을 의미하기 때문에(KICCE, 2011) 양육스트레스와 같은 정서적 특성뿐만 아니라 어머니 의 온정적 양육행동에 나타나는 모-자녀 간 관계적 특성이 반 영된 결과로 해석할 수 있다.

다섯째, 위와 같은 변인들 간의 영향력은 전업모 집단에서 만 모두 유의한 것으로 나타났다. 우울을 통제하였을 때 영아 기 자녀를 키우는 전업모의 양육스트레스 증가가 이후의 양육 행동 및 유아의 사회정서발달에 영향을 미치는 경로를 밝혀냄 으로써, 전업모의 양육스트레스 증가에 대한 관심과 중재가 필요한 이유를 뒷받침하였다고 볼 수 있다. 전업모의 양육스 트레스 초기치가 높고 매년 더 빨리 증가할수록 유아의 정서 성 및 또래상호작용에 부정적인 영향을 미치며, 매개변인이었 던 자녀와의 긍정적인 정서적 상호작용을 의미하는 온정적이 고 반응적인 양육행동을 크게 감소시켰다. 온정적 양육행동의 감소는 특히 영유아기에 자녀의 사회정서발달 뿐만 아니라 다 양한 측면의 발달에 영향을 미칠 수 있는 주요 요인이 될 수 있 다(Music, 2011)는 점에서 전업모의 양육스트레스 증가의 다 양한 예측요인들에 대한 후속 연구가 필요하다. 취업모의 경 우 이러한 변인들 간 영향력이 유의하지 않았던 것은 우울을 통제하였을 때 양육스트레스에 유의한 증가 추세가 나타나지 않았기 때문인 것으로 보인다. 따라서 어머니의 양육스트레 스 및 우울과 같은 정서적 건강에 대한 개입이나 보육지원 정 책은 어머니들의 상황에 따라 다르게 이루어져야 할 것이다. 영아 자녀와 대부분의 시간을 함께 보내는 전업모의 경우 개 인 시간 확보가 어렵고 사회적 관계에서 고립감을 느끼게 되 어 양육스트레스 수준이 더 높을 뿐만 아니라(Sohn, 2012) 양 육스트레스에 대한 대처가 더욱 힘들 수 있다. 2016년 7월부 터 보건복지부에서 0-2세 영아를 대상으로 시행하고 있는 맞 춤형 보육을 포함하여 지금까지 보육정책에 관한 논의들은 주 로 맞벌이가정, 취업모를 중심으로 한 양적 확대에 초점을 두 어 이루어져 왔으나, 하루의 대부분을 자녀와 함께 보내면서 돌봄을 전담하도록 기대되는 전업모의 양육부담과 정서적 건 강에도 정책적 관심이 촉구된다. 만 0-3세 영아를 집에서 돌 보는 전업모의 양육부담을 분산시킬 수 있도록 다양한 유형의 시간제 보육서비스 및 보육정보를 제공하고, 전업모들 간 정 보교류 및 정서적 교류 등을 촉진시킬 수 있는 프로그램 등이 보완될 필요가 있다. 보다 근본적으로는 일과 양육의 균형을
유지할 수 있도록 출산 및 육아휴직 보장, 유연근무제 실시, 양 육 조력자가 아닌 주체로서의 아버지 역할 등에 대한 사회적 합의가 확산된다면 출산과 육아로 인한 경력 단절을 감소시키 고 양육을 전담하거나 일과 양육을 병행하는 것에 대한 실제 적-심리적 부담을 줄이는 데 기여할 수 있을 것이다. 이와 함 께 보육기관에 대한 신뢰도 및 양질의 보육서비스에 대한 접 근성과 유연성을 확보하는 정책이 뒷받침되어야 할 것이다.

본 연구는 어머니의 정서적 특성인 우울에 초점을 두어, 양 육스트레스 변화에 영향을 미칠 수 있는 다양한 변인들을 고 려하지 못하였다는 제한점이 있다. 또한 어머니의 취업여부를 구분할 때 1 차 연도의 취업/학업 상태를 기준으로 집단을 구 분하였는데, 취업/학업 상태가 중도에 바뀐 경우를 반영하지 못하였으므로 추후 연구에서는 취업 상태를 세분화하여 전업, 취업, 재취업, 경력단절 등 다양한 변인을 고려한다면 더욱 의 미 있는 논의가 가능할 것이다. 이 외에도 직장에서의 양육과 관련된 전반적 인식과 배려, 업무 형태 및 강도 등이 취업모의 양육스트레스에 영향을 미치는 또 다른 요인이 될 수 있다(H.N. Park, 2014). 본 연구에서는 영아 자녀를 키우는 어머니의 양육스트레스가 유아 자녀의 발달 결과에 미치는 영향을 살펴 보기 위하여 자녀가 0-3세에 해당하는 4개 연도 자료만을 활 용하여 분석하였는데, 자녀의 발달단계에 따라 이러한 양상은 달라질 수 있으므로 현재 축적되고 있는 패널자료를 토대로 연구가 확장될 필요가 있다.

이러한 제한점에도 불구하고, 본 연구는 영아기 자녀를 키 우는 어머니의 양육스트레스 변화를 종단적으로 분석하고, 양 육스트레스의 증가가 이후의 양육행동 및 유아의 사회정서발 달에 미치는 영향력을 검증하였다는 점에서 연구의 의의를 찾 을 수 있다. 특히 양육스트레스의 종단적 변화를 살펴본 다른 선행연구들과는 달리, 양육스트레스와 함께 어머니의 정서적 건강의 주요 지표라 할 수 있는 우울을 매 시점에서 통제함으 로써 더욱 가파르게 증가하는 양육스트레스의 변화 궤적을 더 욱 명확히 확인할 수 있었다. 또한 이를 취업여부에 따라 비교 하였을 때 취업모 집단에서는 양육스트레스의 증가 양상이 사 라졌으며, 전업모 집단은 여전히 매년 증가하고 있음을 밝혔 다. 이러한 결과는 전업모와 취업모의 양육스트레스는 그 수 준이 다를 뿐 아니라 특성 또한 이질적이라는 점을 시사한다. 나아가 전업모의 누적된 양육스트레스는 직접적으로, 그리고 양육행동을 매개로 하여 간접적으로 유아의 부정적 정서성 및 긍정적 또래상호작용에 영향을 미친다는 점을 밝힘으로써 양 육스트레스의 장기적 영향력을 확인하고 어머니의 정서적 건 강을 위한 중재의 필요성을 뒷받침하였다. 


\section{Conflict of Interest}

No potential conflict of interest relevant to this article was reported.

\section{References}

\section{In English}

Abidin, R. R. (1992). The determinants of parenting behavior. Journal of Clinical Child Psychology, 21(4), 407-412. doi:10.1207/s15374424jccp2104_12

Anthony, L. G., Anthony, B. J., Glanville, D. N., Naiman, D. Q., Waanders, C., \& Shaffer, S. (2005). The relationships between parenting stress, parenting behaviour and preschoolers' social competence and behaviour problems in the classroom. Infant \& Child Development, 14(2), 133154. doi: $10.1002 /$ icd.385

Arbuckle, J. L. (1996). Full information estimation in the presence of incomplete data. In G. A. Marcoulides \& R. E. Schumacker (Eds.), Advanced structural equation modeling: Issues and techniques (pp. 243-277). Mahwah, NJ: Lawrence Erlbaum Associates.

Belsky, J., Hsieh, K.-H., \& Crnic, K. A. (1998). Mothering, fathering, and infant negativity as antecedents of boys' externalizing problems and inhibition at age 3 years: Differential susceptibility to rearing experience? Development and Psychopathology, 10(2), 301-319. doi:10.1017/S095457949800162X

Coplan, R. J., Bowker, A., \& Cooper, S. M. (2003). Parenting daily hassles, child temperament, and social adjustment in preschool. Early Childhood Research Quarterly, 18(3), 376395. doi:10.1016/S0885-2006(03)00045-0

Crnic, K. A., Gaze, C., \& Hoffman, C. (2005). Cumulative parenting stress across the preschool period: Relations to maternal parenting and child behaviour at age 5. Infant and Child Development, 14(2), 117-132. doi:10.1002/icd.384

Cummings, E. M., Davies, P. T., \& Campbell, S. B. (2000). Developmental psychopathology and family process: Theory, research and clinical implications. New York: Guilford Press.

Curran, P. J., West, S. G., \& Finch, J. F. (1996). The robustness of test statics to non-normality and specification error in confirmatory factor analysis. Psychological Method, 1, 1629. doi:10.1037/1082-989X.1.1.16

de Mol, J., \& Buysse, A. (2008). The phenomenology of children's influence on parents. Journal of Family Therapy, 30(2), 163193. doi: 10.1111/j.1467-6427.2008.00424.x
Deater-Deckard, K. (1998). Parenting stress and child adjustment: Some old hypotheses and new questions. Clinical Psychology: Science and Practice, 5(3), 314-332. doi:10.1111/j.1468-2850.1998.tb00152.x

Epifanio, M. S., Genna, V., de Luca, C., Roccella, M., \& la Grutta, S. (2015). Paternal and maternal transition to parenthood: The risk of postpartum depression and parenting stress. Pediatric Reports, 7(2), 38-44. doi: 10.4081/pr.2015.5872

Field, T. (2005). Prenatal depression effects on the fetus and neonate. In J. Nadel \& M. Muir (Eds.), Emotional development (pp. 317-339). New York: Oxford University Press.

Field, T. (2010). Postpartum depression effects on early interaction, parenting, and safety practices: A review. Infant Behavior and Development, 33(1), 1-6. doi:10.1016/ j.infbeh.2009.10.005

Field, T., Diego, M., \& Hernandez-Rief, M. (2006). Prenatal depression effects on the fetus and newborn: A review. Infant Behavior and Development, 29(3), 445-455. doi:10.1016/j.infbeh.2006.03.003

Fonagy, P., Gergely G., Jurist E. L., \& Target, M. (2002). Affect regulation, mentalization, and the development of the self. New York: Other Press.

Gaffan, E. A., Martins, C., Healy, S., \& Murray, L. (2010). Early social experience and individual differences in infants' joint attention. Social Development, 19(2), 369-393. doi:10.1111/j.1467-9507.2008.00533.x

Grossmann, K. E., Grossmann, K., \& Waters, E. (Eds.). (2005). Attachment from infancy to adulthood: The major longitudinal studies. New York: Guilford Press.

Kam, C.-M., Greenberg, M., Bierman, K., Coie, J., Dodge, K., Foster, M., .. . Pinderhughes, E. (2011). Maternal depressive symptoms and child social preference during the early school years: Mediation by maternal warmth and child emotion regulation. Journal of Abnormal Child Psychology, 39(3), 365377. doi:10.1007/s10802-010-9468-0

Kline, R. B. (2005). Principles and practice of structural equation modeling. New York: Guilford Press.

Martins, C., \& Gaffan, E. A. (2000). Effects of early maternal depression on patterns of infant-mother attachment: A meta-analytic investigation. Journal of Child Psychology and Psychiatry, 41(6), 737-746. doi:10.1111/1469-7610.00661

Morrell, J., \& Murray, L. (2003). Parenting and the development of conduct disorder and hyperactive symptoms in childhood: A prospective longitudinal study from 2 months to 8 years. Journal of Child Psychology and Psychiatry, 44(4), 489-508. doi:10.1111/1469-7610.t01-1-00139

Mulsow, M., Caldera, Y. M., Pursley, M., Reifman, A., \& Huston, A. C. (2002). Multilevel factors influencing maternal stress during the first three years. Journal of Marriage and Family, 
64(4), 944-956. doi:10.1111/j.1741-3737.2002.00944.x

Music, G. (2011). Nurturing natures: Attachment and children's emotional, sociocultural, and brain development. East Sussex: Psychology Press.

Murray, L., \& Cooper, P. J. (Eds.). (1997). Postpartum depression and child development. New York: Guilford Press.

Pluess, M., \& Belsky, J. (2010). Differential susceptibility to parenting and quality child care. Developmental Psychology, 46(2), 379-390. doi:10.1037/a0015203

Rothbart, M. K., \& Bates, J. E. (1998). Temperament. In W. Damon, R. Lerner, \& N. Eisenberg (Eds.), Handbook of child psychology: Vol. 3. Social, emotional, and personality development (5th ed., pp. 105-176). New York: Wiley.

Williford, A. P., Calkins, S. D., \& Keane, S. P. (2007). Predicting changes in parenting stress across early childhood: Child and maternal factors. Journal of Abnormal Child Psychology, 35(2), 251-263. doi:10.1007/s10802-006-9082-3

Wisner, K. L., Parry, B. L., \& Piontek, C. M. (2002). Postpartum depression. The New England Journal of Medicine, 347(3), 194-199. doi:10.1056/NEJMcp011542

\section{In Korean}

Choi, H., Yeon, E. M., Kwon, S. J., \& Hong, Y. J. (2013). A longitudinal relationships among maternal perception of father involvement in child care, value of children, parenting knowledge, and parenting stress. Korean Journal of Child Care and Education Policy, 7(2), 21-45.

Chung, M.-R., Kang, S.-K., \& Choi, E.-J. (2014). The structural relationships among the parenting characteristics, play participation and infant's social \& emotional development. Early Childhood Education Research \& Review, 18(5), 373401.

Han, J. A., Kim, J. H., \& Cho, Y. J. (2014). Effects of preschool children's gender, age, temperament, mother's employment status and maternal depression on maternal parenting stress. Journal of Korean Council for Children \& Rights, 18(4), 525-544.

Hong, S. (2000). The criteria for selecting appropriate fit indices in structural equation modeling and their rationales. Korean Journal of Clinical Psychology, 19(1), 161-177.

Jo, S., Chung, H.-J., \& Lee, J.-Y. (2015). Comparative study on the relationships among perception of motherhood ideology, parenting stress, and marital satisfactions of employed and unemployed mothers. Journal of Family Relations Association, 20(1), 25-49.

Kim, H.-O. (2015). The comparison of effects of mother's depression and parenting stress on the emotional development of infants between poor families and non- poor families. The Journal of Child Education, 24(1), 119139.

Kim, K.-W., Doh, H.-S., Kim, S., \& Rhee, S.-H. (2010). The relationship between maternal employment, maternal job characteristics, spousal support, and parenting stress. Korean Journal of Child Studies, 31(5), 101-113.

Korea Institute of Child Care and Education. (2008-2011). Panel Study on Korean Children [Data file and code book]. Seoul: Author.

Korea Institute of Child Care and Education. (2008). Panel Study on Korean Children 2008 (wave 1) assessment profiles. Retrieved from http://panel.kicce.re.kr/kor/ publication/01_02.jsp

Korea Institute of Child Care and Education. (2009). Panel Study on Korean Children 2009 (wave 2) assessment profiles. Retrieved from http://panel.kicce.re.kr/kor/ publication/01_02.jsp

Korea Institute of Child Care and Education. (2011). Penn Interactive Peer Play Scale (PIPPS) profile. Retrieved from http://panel.kicce.re.kr/kor/publication/01_02.jsp

Kwon, M. K. (2011). Parenting stress and related factors of employed and non-employed mothers with infants. Journal of Korean Child Care and Education, 7(2), 19-41.

Kwon, M. K., Choi, E. Y., Kim, N. Y., Kim, H. J., \& Lim, J. B. (2016). A study on settlement plans of child care culture focusing on demanders of policy (Research Report 201602). Retrieved from Korea Institution of Child Care and Education website: http://www.kicce.re.kr/kor/ publication/02_04.jsp

Lee, H.-J. (2011). Mediating effect of maternal parenting stress on prenatal depression and infants' difficult temperament. Journal of the Korean Society of Child Welfare, 35, 99-126.

Lee, H.-J. (2013). A longitudinal study on the maternal parenting stress: The use of a latent growth model. Proceedings of the 4th International Conference on Panel Study on Korean Children, 251-271. Retrieved from http://panel.kicce.re.kr/ kor/inquiry/04.jsp

Lee, J., \& Lee, B. R. (2013). The effects of changes of parenting stress, child care subsidy, satisfaction on child care institution and community's nurturing environment on the additional childbirth intention. Proceedings of the 4 th International Conference on Panel Study on Korean Children, 369-387. Retrieved from http://panel.kicce.re.kr/kor/ inquiry/04.jsp

Lee, Y., \& Chin, M. (2013). Social capital and parental stress of married mothers with young children: Variations by employment status. Family and Environment Research, 51(2), 229-239.

Park, H.-N. (2014). Sleep health, psychological distress, parenting stress, marital satisfaction of working mothers according 
to employment status and working pattern. The Journal of Korea Open Association for Early Childhood Education, 19(6), 423-441.

Park, S., No, B., Park, H. J., \& Yi, S.-H. (2015). The structural relationship among trajectories of mothers' parenting stress, children's temperament and internalizing problems: Multiple group analysis according to employment status of mothers. Korean Journal of Child Care and Education Policy, 9(1), 119-148.

Shin, J.-Y. (2011). Relations among child's temperament, parenting stress and parenting practices: The mediating role of parenting stress. Early Childhood Education Research \& Review, 15(2), 291-312.

Sohn, S. M. (2012). Parenting stress and related factors of employed and non-employed mothers with infants. Journal of Future Early Childhood Education, 19(1), 331-357.

Son, S. H., Lee, Y. S., Bae, S. Y., Han, C. H., Yoo. J. Y., Lee, M. J., \& Cho, H. R. (2010). A study on related factors to parenting stress of employed and non-employed mothers: Focus on 4 to 9 months infant mother's emotional cognitive characteristics, marital relationship and social support. Proceedings of the 1st Conference of Panel Study on
Korean Children, 663-682. Retrieved from http://panel. kicce.re.kr/kor/inquiry/04.jsp

Song, Y. J., Lee, M. R., \& Chun, H. Y. (2014). Parenting stress changes in both of continuous working and non-working mothers after the birth of their first child: A focus on the effects of the values, knowledge, and expectations about their children. Korean Journal of Child Studies, 35(5), 1535. doi:10.5723/KJCS.2014.35.5.15

\section{ORCID}

Saerom Park

http://orcid.org/0000-0001-6863-5406

Hye Jun Park

Received June 30, 2016 Revision received August 5, 2016

Accepted August 8, 2016 